\title{
Evaluation of Soil Water Index of distributed Tank Model in a small basin with field data
}

\author{
Sofia Melo Vasconcellos ${ }^{1}$, Masato Kobiyama ${ }^{1}$, and Aline de Almeida Mota ${ }^{2}$ \\ ${ }^{1}$ Institute of Hydraulic Researches, Federal University of Rio Grande do Sul, Porto Alegre, Brazil \\ ${ }^{2}$ Department of Environmental and Sanitary Engineering, Federal University of Fronteira Sul, Chapecó, Brazil \\ Correspondence: Sofia Melo Vasconcellos (sofia.vasconcellos@ufrgs.br)
}

\begin{abstract}
The objective of the present study was to determine the spatial behaviour of the Soil Water Index (SWI) by applying a distributed version of the Tank Model (D-Tank Model) to the Araponga river basin (5.26 ha) in southern Brazil and to verify its reliability through the comparison to soil moisture estimated with the measured water-tension values and the water retention curve. The study area has a monitoring system for rainfall, discharge (5- min interval), and soil-water tension (10-min interval).

5 The simulation results showed that the D-Tank Model has a reliable performance. The correlation between SWI and HAND was reasonable ( $\mathrm{r}=0.6)$ meanwhile that between SWI and the Topographic Wetness Index was high ( $\mathrm{r}=0.88)$. The comparison between the spatially distributed values of the SWI and soil moisture confirmed the high potential of the SWI derived from the D-Tank Model to be applied for predictions related to hydrological and environmental sciences. Keywords: D-Tank Model, Soil Water Index, Topographical Wetness Index, HAND, Soil Moisture.
\end{abstract}

\section{Introduction}

Soil moisture is very important in the energy and water exchanges between pedosphere and atmosphere, which exert direct influence on the processes of infiltration, drainage, evapotranspiration, surface runoff, among others (Entin et al., 2000). Therefore, soil moisture is widely used as a variable in a lot of environmental, hydrological, meteorological and agricultural studies (Walker et al., 2004). It is well known that the spatio-temporal monitoring of soil moisture supports better management of water resources, prediction of floods and droughts, and so on. In spite of its importance, representing the spatial variation patterns of soil moisture is challenging (Mälicke et al., 2019), and this variable is not regularly monitored due to the high cost (Brocca et al., 2017).

To fill this gap, various methods for estimating soil moisture condition have been proposed. For example, the use of satellite measurements such as Soil Moisture and Ocean Salinity - SMOS (Kerr et al.,2001; Gumuzzio et al.,2016), indexes relating soil moisture condition to antecedent precipitation such as the Antecedent Precipitation Index - API (Kohler and Linsley, 1951), and API-mod (Pellarin et al., 2013), indexes relating to soil moisture such as Soil Water Index (Okada et al.,2001;Paulik et al.,2014; Grillakis et al.,2016), Tank Moisture Index (Lindner and Kobiyama, 2009), Soil Moisture Index (Carrão et al., 2016), Soil Moisture Drought Index (Sohrabi et al., 2016), Soil Wetness Index (Saleem and Salvucci, 2002), and Soil moisture state (Zhuo and Han, 2017) and Topographical Wetness Index (TWI) (Beven and Kirkby, 1979) The relation between TWI and 
https://doi.org/10.5194/hess-2019-682

Hydrology and

Preprint. Discussion started: 28 January 2020

(c) Author(s) 2020. CC BY 4.0 License.

soil moisture have been explored by several authors (Sørensen et al., 2006; Radula et al.,2018; Kim, 2012; Metzen et al.,2019). Similarly to the TWI, Rennó et al. (2008) found that the elevation difference to the nearest stream was correlated to soil water content distribution and proposed a new model, Heigh Above the Nearest Drainage (HAND). And both TWI and HAND are considered indicators of flood-prone areas (Nardi et al.,2006; Manfreda et al., 2015; Zheng et al.,2018; Tavares da Costa et al.,2019), and for landscape classification (Gharari et al.,2011; Loritz et al.,2019).

Physically-based distributed models have shown suitability for studying soil moisture and runoff response (Castillo et al.,2003; Loritz et al.,2019). Furthermore, some distributed hydrological models, such as WBMGB proposed by Saldanha et al. (2012) which divides the analyzed area into square cells of 10-km resolution, spatially calculate the water balance in the soil and consequently deal with soil moisture conditions. Sheikh et al. (2009) developed the BEACH model, a simple two-layer soil water balance model that provides spatially distributed initial soil moisture content. They emphasized the importance of soil moisture in hydrological modeling. Rahmati et al. (2018) also concluded that it is important to evaluate the basin physical characteristics like soil moisture, in order to properly understand the hydrogeomorphic processes therein.

As soil moisture condition results from a water cycle, it is quite reasonable to treat it in the context of hydrological models simulating the water balance. One of the classic hydrological models is the Tank Model proposed by Sugawara (1961, 1995), which is originally lumped and deterministic. This model was well evaluated and recommended by World Metereological Organization (WMO) $(1975,1992)$ and Franchini and Pacciani (1991). Since it is computationally simple and generates good results of hydrograph estimation, this model has been applied to various issues, for example, landslide prediction (Kobaishi and Suzuki,1987; Shuin et al.,2013; Nie et al.,2017); debris flow investigation (Takahashi and Nakagawa, 1991); flood forecasting (Tingsanchali and Gautam, 2000); Paddy field management (Chen et al., 2003); water quality (Kato, 2005); and sediment yield estimate (Lee and Singh, 2005), and also modified to its distributed version (Kato et al.,2005; Huang et al.,2007).

The Tank Model was initially considered a storage model, composed of a series of vertical reservoirs (tanks), which schematically represents the stratification of the soil layers from the surface to the base. The hypothesis based on this model structure is that the sum of the water storage calculated in these tanks would be a representative measure of the real condition of soil moisture in the basin. Then, the Soil Water Index and Tank Moisture Index derived from the Tank Model were proposed by Okada et al. (2001) and by Lindner and Kobiyama (2009), respectively. Thus, the use of the Tank Model as well as these indexes can be very useful in hydrological studies and, consequently, in natural disasters, water resources and basin managements (Saito and Matsuyama,2012; Chen et al.,2013; Oku et al.,2014; Mukhlisin et al.,2015; Saito and Matsuyama,2015; Jun,2016; Chen et al.,2017;Matlan et al.,2018). However, the relationship between the water storage of each tank and the real soil moisture condition measured in a real basin has never been evaluated.

The objective of the present study was, therefore, to propose a distributed version of the Tank Model, to take into account the model and parameter uncertainties to compare the Soil Water Index (SWI) of Okada et al. (2001) with soil moisture indicators (TWI and the HAND topology), and to compare the results with the soil moisture obtained in a small experimental basin. 


\section{Methods}

\subsection{Study Area}

The study area is Araponga river basin (5.26 ha) which is a small experimental basin located in the rural area of Rio Negrinho municipality of the Santa Catarina state, southern Brazil. In this basin, the mean slope of the main channel and drainage density are $0.30 \mathrm{~m} . \mathrm{m}^{-1}$ and $9.62 \cdot 10^{3} \cdot \mathrm{m}^{-1}$ respectively (Mota et al., 2017). According to Alvares et al. (2013), the climate of the region is classified as $\mathrm{Cfb}$ - Humid subtropical, oceanic climate, without dry season, with temperate summer.

The basin is covered with the Mixed Ombrophilous Forest (Araucaria Forest or Brazilian Pine Forest) forming Montana (altitudes between 400 and $1000 \mathrm{~m}$ ). The predominant soil in the region is the Cambisol, moderate and prominent with medium and clayey texture. (Santa Catarina, 1986). From field survey, Mota (2017) identified two soil layers and denominated the top one as A and the subsurface layer as B. The layer A is $0.2-\mathrm{m}$ thick and characterized as a dark brown soil with $78 \%$ sand, $18 \%$ silt, and $4 \%$ clay. The layer B is 1.2-m thick and characterized as a dark yellow soil with 19\% sand, 28\% silt, and 53\% clay).

Figure 1(a) shows the hypsometric map of the basin and, also the location of the rain gauge, the discharge weir and 9 tensiometer-batteries. The rainfall and discharge data were automatically measured in 5-min interval and, soil water tension data every 10 minutes.

According to Mota et al. (2017), the tensiometer sensors were installed by considering the soil depth and profile along the three hillslopes selected for the monitoring. In each hillslope, there were three points of tensiometer-batteries: near the river (higher slope with a mean soil depth of $0.5 \mathrm{~m}$ ), at the middle hillslope (smaller slope with soil depths from 1.0 to $1.9 \mathrm{~m}$ ), and near the basin divisor (smaller slope with soil depths from 1.0 to $1.9 \mathrm{~m}$ ). Therefore, considering the variability of soil depth along each hillslope, there were adopted two configurations for the depths' distribution of the soil water tension sensors. The type II configuration is characterized with the points very near the river (tensiometers A12, B12 and Z12), and the type I configuration with the other points (tensiometers A3, A4, B3, B4, Z3 and Z4). For the type II, 2 sets with 3 sensors were installed, at the $0.1 \mathrm{~m}, 0.3 \mathrm{~m}$ and $0.4 \mathrm{~m}$ depths. The type $\mathrm{I}$ was used at the points where the soil layer was deeper, which allowed the installation of 7 sensors at the depths $0.1 \mathrm{~m}, 0.2 \mathrm{~m}, 0.3 \mathrm{~m}, 0.4 \mathrm{~m}, 0.6 \mathrm{~m}, 0.75 \mathrm{~m}$ and $0.90 \mathrm{~m}$. Their locations are shown in Figure 1(b). The tensiometers used for the measurements were of the Irrometer Watermark, model 200SS.

\subsection{Used Data}

The topographic information of the basin was extracted from the digital elevation model (DEM) of the Araponga basin at 1:5000 scale of 1-m resolution that was generated through the topographic survey carried out by Mota et al. (2017).

The precipitation and discharge data used in the present study were obtained during the period from March 2011 to December 2015 as showed in Figure 2. The evapotranspiration was calculated from the measurements at the Feio meteorological station, located $3 \mathrm{~km}$ distant from the Araponga basin, using the same procedure of Lindner and Kobiyama (2009) which utilized the Penman modified method of Doorenbos and Pruitt (1977).

By using the equation of Van Genuchten (1980), Mota (2017) estimated the parameters of the water retention curves for the two soil-layers of the study area from 12 undisturbed soil samples (6 at 10-cm depth and 6 at $50-\mathrm{cm}$ depth) collected near 

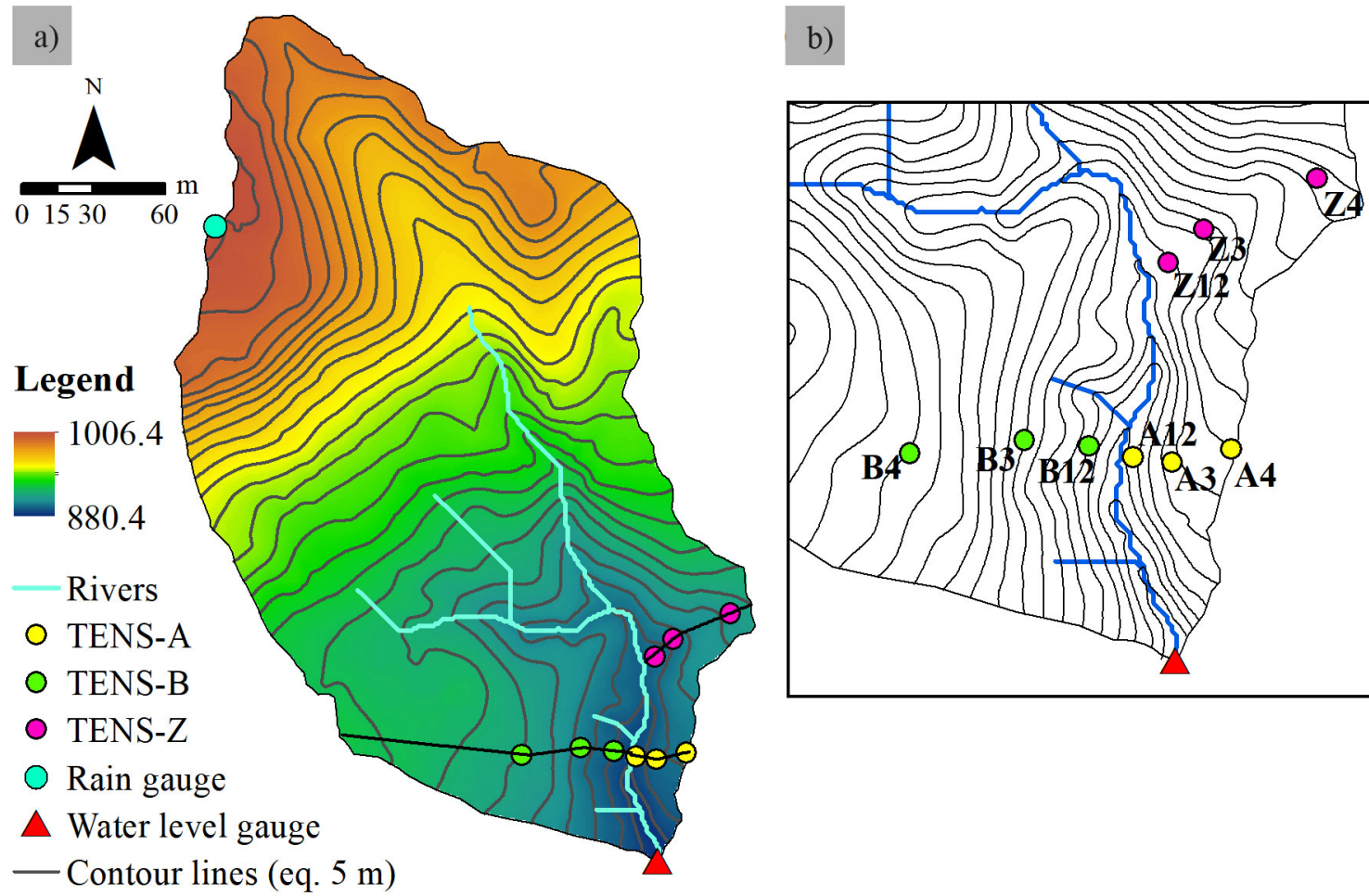

Figure 1. (a) Hypsometric map of the experimental Araponga river basin and location of the monitoring devices installed (Source: (Mota et al., 2017)), (b) Detail of the location of the tensiometers.

Table 1. Parameters of the water retention curves. Source: Mota (2017)

\begin{tabular}{lll}
\hline & Layer A & Layer B \\
\hline$\Theta_{r}\left(\mathrm{~cm}^{3} / \mathrm{cm}^{3}\right)$ & 0.0896 & 0.3773 \\
$\Theta_{s}\left(\mathrm{~cm}^{3} / \mathrm{cm}^{3}\right)$ & 0.6511 & 0.5518 \\
$K_{s}(\mathrm{~cm} / \mathrm{s})$ & $4.05 \cdot 10^{3}$ & $4.63 \cdot 10^{4}$ \\
$\alpha\left(\mathrm{cm}^{-1}\right)$ & 0.0004 & 0.0011 \\
$\mathrm{n}$ & 1.6165 & 3.6782 \\
$\mathrm{~m}$ & 0.3814 & 0.7281 \\
\hline
\end{tabular}

90 the installed tensiometers. These samples were subjected to predefined pressures $(500,1000,3000,6000$ and $10000 \mathrm{~cm})$ in the Richards pressure plate until the drainage stabilized and then their water contents were determined. The RETC program (Van Genuchten et al., 1991) was used to fit the retention curves from pressure head and soil water content (Table 1). 
https://doi.org/10.5194/hess-2019-682

Preprint. Discussion started: 28 January 2020

(c) Author(s) 2020. CC BY 4.0 License.

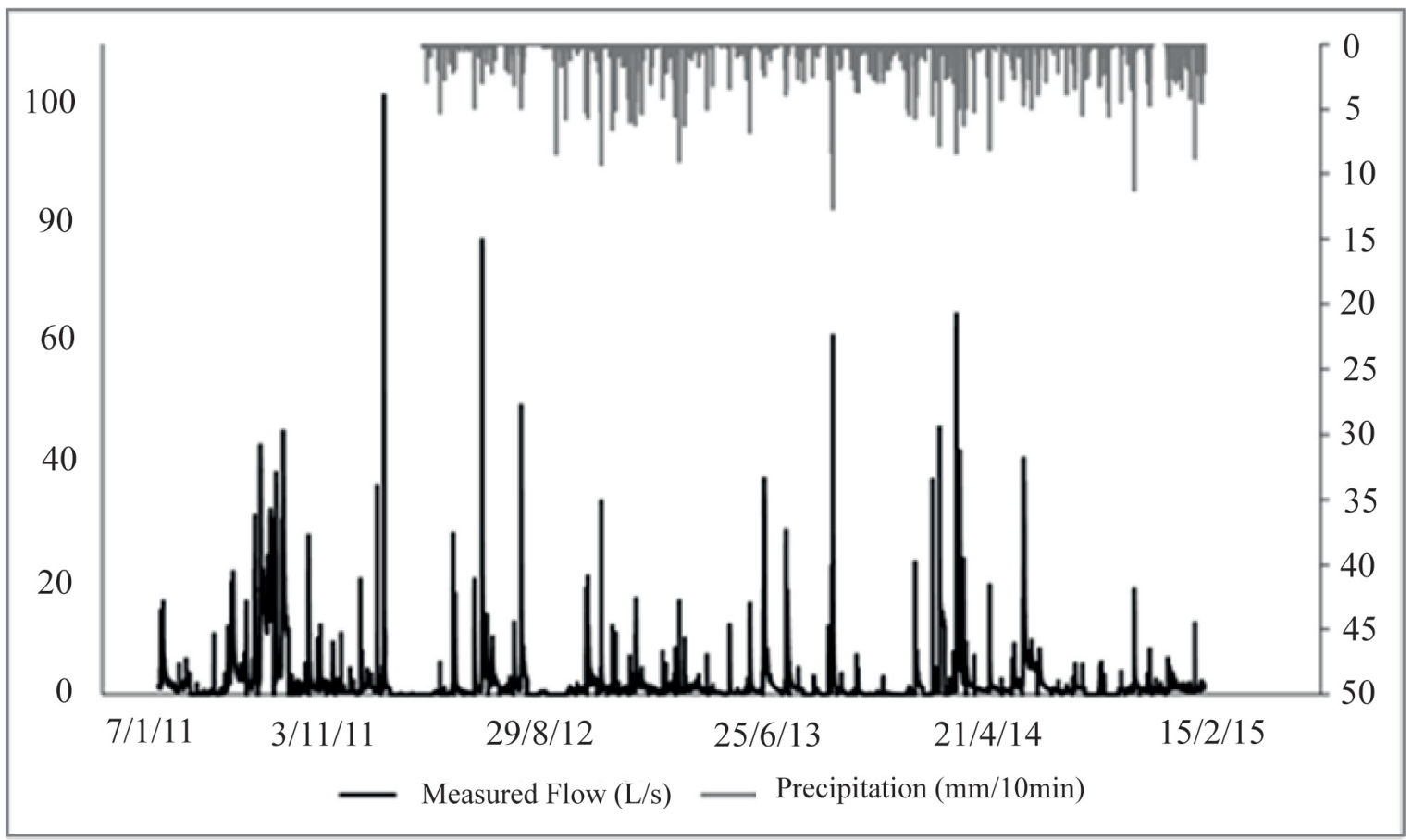

Figure 2. Measured flow and Precipitation data.

The soil water content was estimated by using the water retention curves and the water tension data measured at the depths of $0.10 \mathrm{~m}, 0.20 \mathrm{~m}, 0.30 \mathrm{~m}, 0.40 \mathrm{~m}, 0.60 \mathrm{~m}, 0.75 \mathrm{~m}$, and $0.90 \mathrm{~m}$. For determining the time interval (T) used for Tank Model simulations to a certain basin area $\mathrm{A}\left(\mathrm{km}^{2}\right)$, (Sugawara, 1995) suggested the following equation:

$T=0.15 \sqrt{A}$

Since $\mathrm{A}=0.0524 \mathrm{~km}^{2}$ in the present study, $\mathrm{T}$ is $0.034 \mathrm{~h}$, approximately $2.1 \mathrm{~min}$. As the field measurement was conducted every 5 minutes, the value of 5 minutes was adopted for $\mathrm{T}$.

The hydrological and the water tension data series presented many periods of no-data caused by technical problems with the sensors. For this reason, it was not possible to use the entire series of data obtained by the monitoring. Thus, there were selected 5 rainfall events for calibration and 2 for validation which all lasted 3 days. Table 2 shows the period, the mean, cumulative, measured and calculated values of precipitation and flow and the mean and cumulative values of evapotranspiration for the calibration events: I (occurred between January 14th to 16th, 2012), II (occurred between April 28th to 30th, 2012), III (occurred between June 4th to 6th, 2012), IV (occurred between June 20th to 22nd, 2013), V (occurred between March 8th to 
https://doi.org/10.5194/hess-2019-682

Preprint. Discussion started: 28 January 2020

(c) Author(s) 2020. CC BY 4.0 License.

Table 2. Hydrological data of rainfall events used in calibration and validation.

\begin{tabular}{llllllll}
\hline & I & II & III & IV & V & VI & VII \\
\hline Mean precipitation (mm/5min) & 0.063 & 0.046 & 0.140 & 0.120 & 0.100 & 0.120 & 0.160 \\
Accumulated Precipitation (mm) & 54.90 & 40.60 & 122.92 & 107.13 & 84.62 & 104.59 & 139.12 \\
Average flow $\left(\mathrm{m}^{3} / \mathrm{s}\right)$ & 0.0037 & 0.0037 & 0.014 & 0.014 & 0.014 & 0.0044 & 0.011 \\
Average flow (mm/5min) & 0.021 & 0.021 & 0.080 & 0.080 & 0.080 & 0.025 & 0.060 \\
Accumulated flow (mm) & 17.82 & 18.33 & 71.81 & 68.86 & 64.92 & 21.45 & 23.11 \\
Average ETR (mm/5min) & 0.00310 & 0.00150 & 0.00001 & 0.00300 & 0.00500 & 0.00150 & 0.00130 \\
Accumulated ETR (mm) & 2.72 & 1.32 & 0.07 & 2.34 & 4.26 & 1.32 & 1.14 \\
\hline
\end{tabular}

10th , 2014); and validation events: VI (occurred between July 20th to 22nd, 2013) and VII (occurred between April 25th to 27th , 2012).

\subsection{Tank Model}

According to Sugawara (1995), the number of tanks used in the modeling depends on the basin size, the soil type and use, and the time interval used in the simulation. In the case of large basins, and long-term simulations with daily data, there is a strong influence of the base flow, so a 4-tanks structure is used to represent the hydrological processes. In the case of small basins, where short rainfall events will be evaluated, the greatest contribution to the flow will come from the surface runoff because the time response of the basin is too fast, and a few tanks are needed. For this reason, a 2-tanks structure was chosen for simulating the rainfall-discharge processes and estimating of soil moisture (Figure 3 (a)).

Then, the water balance equations were considered. Two versions of the Tank Model were applied in the study area. At first, the lumped Tank Model was created in order to obtain the parameters to be used in the distributed model. Secondly, apart from the parameters encountered in the first step, the distributed Tank (D-Tank) Model was established.

The application of the lumped model was carried out by considering the structure composed of two tanks (reservoirs), and the equation for the flow calculation was obtained as follows:

$q s 1=a 1 \cdot(S 1-H A 1)$

$q s 2=a 2 \cdot(S 1-H A 2)$

$q s 3=b 1 \cdot S 2$ 

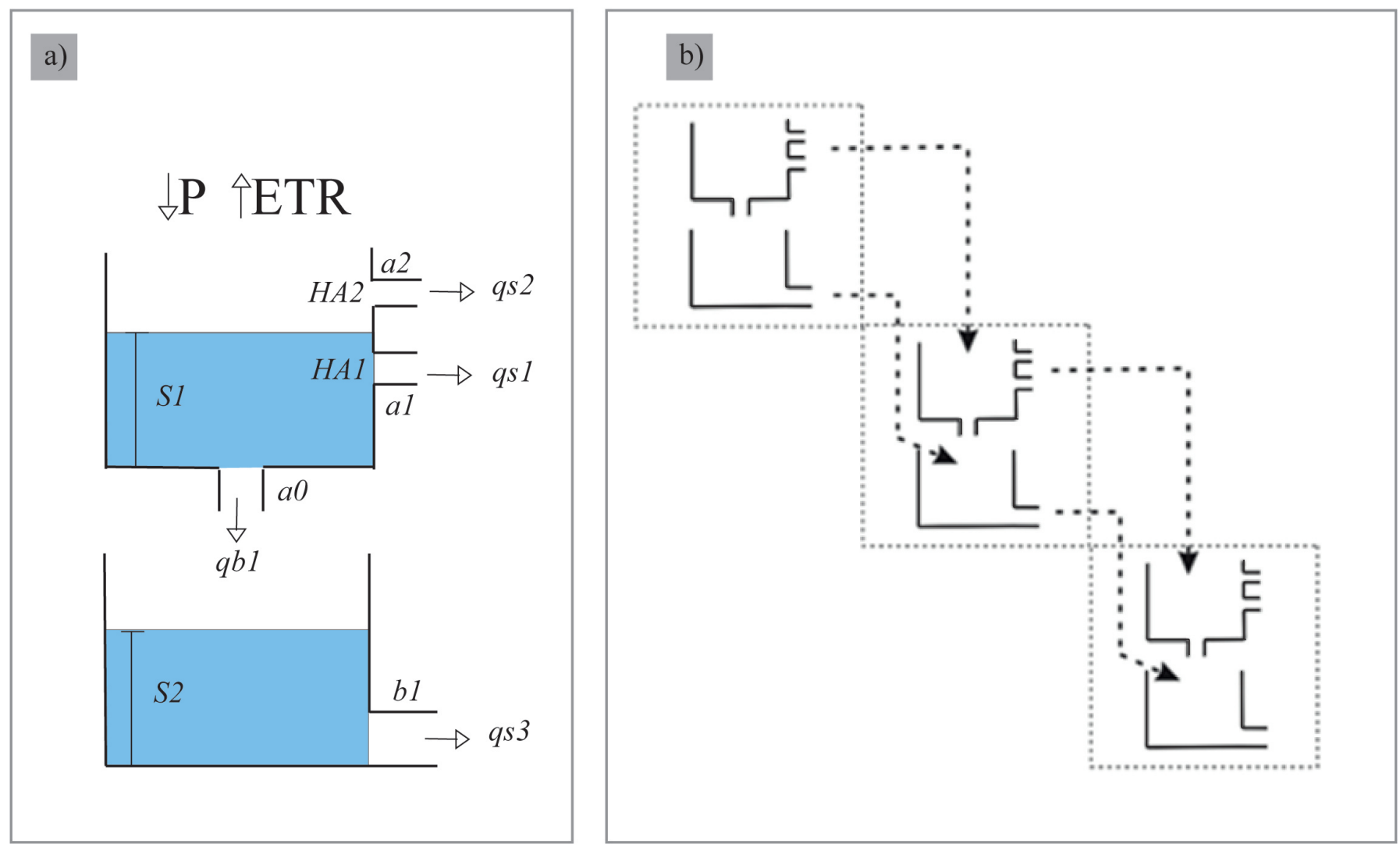

Figure 3. Structure of the Tank Model. (a) in a single cell; and (b) schematic representation of the movement of the flow between cells. P is the precipitation and ETR is the evapotranspiration, both in $\mathrm{mm} / 5 \mathrm{~min}$.

where $\mathrm{S}$ is the height of water stored in each tank $(\mathrm{mm})$; qs2, qs1 and qs3 represent the surface, sub-surface and groundwater flow, respectively ( $\mathrm{mm} / 5 \mathrm{~min})$; qb1 is the percolation from the upper to the lower tank $(\mathrm{mm} / 5 \mathrm{~min})$; a1, a2, and b1 are the coefficients of discharge; and a0 the coefficient of percolation; and HA1 and HA2 are the heights of the upper tank holes.

The present study calls the flow and percolation coefficients of all the holes, and the heights of the lateral and vertical holes of each tank as model parameters. These parameters' values are usually obtained through calibration. According to Ishihara and Kobatake (1979), they are related to the soil type and use as well as to geological characteristics of the basin. 
https://doi.org/10.5194/hess-2019-682

Preprint. Discussion started: 28 January 2020

(c) Author(s) 2020. CC BY 4.0 License.

For the application of D-Tank Model, the study area was divided into square cells, with 2-m resolution. In each of them, the lumped Tank Model with the equations (2) to (5) was applied.

The flow traveled through the cells depending on slope, where the upper tank of one cell passed to the upper tank of the next cell (Figure 3 (b)). Thus, each of the tanks cell received flow generated by neighboring cells, which calculation is as follows:

$Q=\Sigma c \cdot \Sigma j \cdot q_{i, j}$

where $\mathrm{Q}$ is the total flow received by the adjacent tank; $\mathrm{q}$ is the flow calculated by lateral orifice; i represents the tank (1: upper tank, 2 lower tank); $\mathrm{j}$ is the lateral hole; and $\mathrm{c}$ is the number of cells that send outflow directly to the considered cell. The water storage in each tank was equal to that used by Kato et al. (2005), and determined by the following equations:

$S 1_{t}=S 1_{t-1}+P-E T R+\frac{Q 1}{C t}-\Sigma j \cdot q_{1, j}$

$S 2_{t}=S 2_{t-1}+q b 1+\frac{Q 2}{C t}-\Sigma j \cdot q_{2, j}$

where $\mathrm{P}$ is the precipitation; $\mathrm{Ct}$ is the total number of covered cells; Q1 and Q2 are the total flow received by the upper and lower tank, respectively; and $\mathrm{t}$ is the time step.

The present work adopted the D-infinity method proposed by (Tarboton, 1997) to determine flow direction between the neighboring cells. This method calculates the flow direction (represented by an angle between 0 and $2 \pi$ rad), which is determined by the steepest direction of the eight triangular facets formed on a grid of $3 \times 3$ cells, centered on the pixel of interest.

\subsection{Soil Water Index}

As aforementioned, there are two indexes derived from the Tank Model which indicate the soil moisture condition in a basin: Soil Water Index - SWI (Okada et al., 2001), and the Tank Moisture Index - TMI (Lindner and Kobiyama, 2009). Both were analyzed for their applicability to prediction and understanding of different natural disasters, the first one focusing on landslides (Okada et al., 2001), and the second one on flood and drought occurrences (Lindner and Kobiyama, 2009). Because of its simplicity, the SWI was adopted in the present study.

According to Okada et al. (2001), the SWI is defined as the sum of the storage heights (S1, S2) of the Tank Model, which indicates the soil moisture condition of the basin in the lumped version and of each cell in the distributed version, i.e.,

$S W I=S 1+S 2$

\subsection{Topographic Wetness Index and HAND}

Beven and Kirkby (1979) proposed the Topographic Wetness Index (TWI) to quantify topographic control on hydrological processes. This index is calculated by

$160 T W I=\ln \frac{\alpha}{\tan \beta}$ 
where $\alpha$ is the flow accumulation in a catchment area; and $\tan \beta$ is the slope. In the present study, the flow accumulation was calculated by using D-infinity algorithm. The slope was calculated in degrees, and after transformed into radians.

The Heigh Above the Nearest Drainage (HAND) proposed by Rennó et al. (2008) was calculated using the software TerraViewHidro. The generated HAND topology was reclassified aiming to better represent the basin characteristics.

\subsection{Calibration and Uncertainty Analysis of Model Parameters}

In order to perform an automatic calibration and uncertainty analysis of model parameters, the present work applied the automatic calibration algorithm Differential Evolution Adaptive Metropolis (DREAM(ZS)) proposed Laloy and Vrugt (2012) and Vrugt (2016). DREAM (ZS) is used for predict uncertainty in hydrological models (Cunha David et al., 2019), and is used for calibration of soil moisture distributed models (Linde and Vrugt, 2013). DREAM algorithm uses Bayesian inference for estimation of model parameter values and their uncertainty. The used number $(\mathrm{N})$ of Markov chains was 3 and the number $(\mathrm{T})$ of generations was 15000 .

In the present study a generalized likelihood function (GL) proposed by Schoups and Vrugt (2010) was used for the inference of the hydrological model parameters. The residual model used a homoscedastic Gaussian likelihood distribution.

The last 7500 sets of parameters sampled with the DREAM (ZS) algorithm were used to represent the uncertainty associated with the parameter values and to create the probabilistic streamflow simulations. The present study evaluated the performance of the models through two functions: the Nash-Sutcliffe efficiency coefficient (NASH) proposed by Nash and Sutcliffe (1970) and the root mean square error (RMSE):

$$
\begin{aligned}
& N A S H=1-\frac{\sum_{n=1}^{T}(\operatorname{Qobs}(t)-Q \operatorname{sim}(t))^{2}}{\sum_{n=1}^{T}(\operatorname{Qobs}(t)-\bar{Q} o b s)^{2}} \\
& R M S E=\sqrt{\frac{1}{t} \cdot \sum_{n=1}^{T}(\operatorname{Qobs}(t)-Q \operatorname{sim}(t))^{2}}
\end{aligned}
$$

where Qobs $(\mathrm{t})$ and Qsim( $(\mathrm{t})$ are the observed and simulated flows at the time $\mathrm{t}$, respectively; and $(\bar{Q} o b s)$ is the mean value of the observed flow along the horizon $\mathrm{t}=1$ to $\mathrm{T}$. The NASH values vary from $-\infty$ to 1 . The RMSE is always positive, and RMSE $=0$ means the perfect adjustment. These two functions were used also for evaluating the model validation.

\subsection{Application Procedure}

The first step of the work was the MATLAB implementation of the Tank Model and D-Tank Model which is similar to that proposed by Kato et al. (2005). At this step, the algorithm was also implemented to calculate the flow direction in the study area.

After, when the distributed version was implemented, it was necessary to divide the study area into square cells with 2-m side, because the available DEM had 1-m resolution, and in the present study it was adopted 2-m resolution. This procedure was 
https://doi.org/10.5194/hess-2019-682

Preprint. Discussion started: 28 January 2020

(c) Author(s) 2020. CC BY 4.0 License.

(c) (i)

Table 3. Range of the Tank Model parameters used in the calibration.

\begin{tabular}{lcr}
\hline Parameter & Minimum & Maximum \\
\hline S1I $(\mathrm{mm})$ & 0.0 & 1.5 \\
S2I $(\mathrm{mm})$ & 70.0 & 75.0 \\
HA2 $(\mathrm{mm})$ & 0 & 70 \\
HA1 $(\mathrm{mm})$ & 0 & 35 \\
a1 $\left(5 \mathrm{~min}^{-1}\right)$ & 0.0001 & 0.09 \\
a2 $\left(5 \mathrm{~min}^{-1}\right)$ & 0.0001 & 0.09 \\
a0 $\left(5 \mathrm{~min}^{-1}\right)$ & 0.00001 & 0.009 \\
b1 $\left(5 \mathrm{~min}^{-1}\right)$ & 0.0001 & 0.09 \\
\hline
\end{tabular}

performed in the ArcMap geoprocessing software, through the ETGeowizards extension which allowed the grid generation, used to calculate the flow directions used in the D-Tank Model.

At the following step, 5 rainfall-events were selected for the calibration of the Tank Model through the DREAM(ZS) algorithm. For each event, a set of parameters was chosen, and this set was also applied to each cell of the D-Tank Model.

This transfer of parameters was validated as follows: for each parameter found in the five events of the previous step, its average was calculated to obtain a single set of parameters to be used for the model validation with two rainfall events.

As aforementioned, the parameters used in the validation step were those corresponding to the mean values of the parameters obtained in the calibration. Two periods were selected for validation of the distributed model, both with 3-days duration.

For the events of the validation period, the SWI values were compared through the linear correlation coefficient (r) with the calculated soil moisture values. Furthermore, the SWI values were also compared with TWI and HAND values.

\section{Results and Discussion}

\subsection{Calibration and Uncertainty Analysis}

The DREAM (ZS) was performed within a range pre-established by the user with the minimum and maximum limits of the decision variables which are the Tank parameters. Those limits are listed in Table 3.

Figure 4 presents the predictive uncertainty for each event selected for calibration, which permits to understand how the uncertainty in the model parameters translates into Tank Model uncertainty. The model seems to be able to match the peak of the hydrographs, but the representation of the smaller flow values could be better. The events I, IV and V possess less uncertainty than events II and III. The set of parameters selected after the automatic calibration for each of the 5 analyzed events is listed in Table 4. These values were used later by the D-Tank Model. 

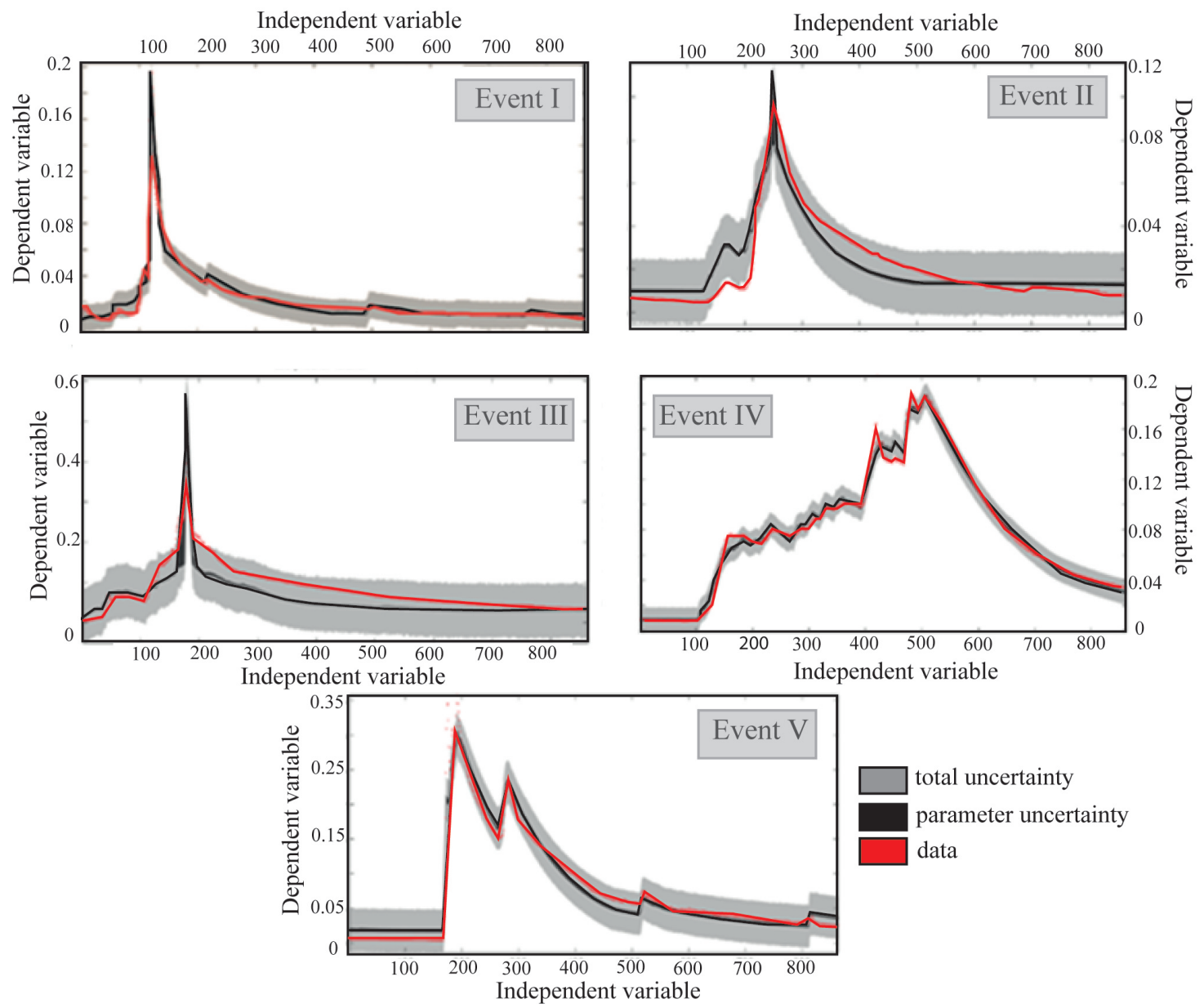

total uncertainty

parameter uncertainty

$\square$ data

Figure 4. Observed runoff series (red), 95\% uncertainty (light grey) and uncertainty associated with the values of the parameters (dark grey).

Table 5 shows the performance of the Tank Model and the D-Tank Model evaluated with two objective functions (NASH and RMSE) for each event. The values of both functions indicate a good fit of the Tank Model as well as the D-Tank Model, and that the set of parameters of the Tank Model is suitable for that of all the cells in the D-Tank Model. It is probably because the study area has uniform land-use and that precipitation and evapotranspiration were also considered uniform over the whole basin area.

In general, the lumped model presented a reliable performance in relation to the observed hydrograph, both in magnitude and in time, especially at the peaks. There was an underestimation event occurred during the period June 4th to 6th, 2012 (Event III), in which a peak flow was observed from $0.43 \mathrm{~mm} / 5 \mathrm{~min}$, and other occurred between April 28th and 30 th, 2013 (Event II), 
https://doi.org/10.5194/hess-2019-682

Preprint. Discussion started: 28 January 2020

(c) Author(s) 2020. CC BY 4.0 License.

Table 4. Tank Model parameters calculated in the calibration for each event.

\begin{tabular}{ccccccc}
\hline Parameter & Event I & Event II & Event III & Event IV & Event V & Mean \\
\hline S1I (mm) & 0.20 & 1.28 & 1.16 & 1.50 & 1.50 & 1.045 \\
S2I (mm) & 72.87 & 74.61 & 72.87 & 75.00 & 75.00 & 73.68 \\
HA2 (mm) & 2.00 & 18.18 & 8.06 & 8.00 & 10.00 & 7.79 \\
HA1 (mm) & 28.40 & 55.32 & 35.00 & 50.00 & 50.00 & 49.94 \\
a1 $\left(5 \mathrm{~min}^{-1}\right)$ & 0.0020 & 0.0038 & 0.0043 & 0.0046 & 0.0056 & 0.0032 \\
a2 $\left(5 \mathrm{~min}^{-1}\right)$ & 0.0500 & 0.0329 & 0.0031 & 0.0003 & 0.0090 & 0.0347 \\
a0 $\left(5 \mathrm{~min}^{-1}\right)$ & 0.0069 & 0.0009 & 0.0057 & 0.0019 & 0.0020 & 0.0032 \\
$\mathrm{~b} 1\left(5 \mathrm{~min}^{-1}\right)$ & $9.42 \cdot 10^{-5}$ & $9.09 \cdot 10^{-5}$ & $3.63 \cdot 10^{-4}$ & $2.70 \cdot 10^{-5}$ & $2.70 \cdot 10^{-5}$ & $6.69 \cdot 10^{-5}$ \\
\hline
\end{tabular}

Table 5. Calibration performance of the Tank Model (TM) and the D-Tank Model (DTM) evaluated with two objective functions for 5 events.

\begin{tabular}{c|cccc}
\hline & NASH & RMSE & NASH & RMSE \\
\hline Event & \multicolumn{2}{c}{ TM } & \multicolumn{2}{c}{ DTM } \\
\hline I & 0.94 & 0.005 & 0.72 & 0.011 \\
II & 0.91 & 0.006 & 0.72 & 0.010 \\
III & 0.92 & 0.015 & 0.85 & 0.022 \\
IV & 0.94 & 0.011 & 0.89 & 0.016 \\
V & 0.89 & 0.025 & 0.88 & 0.026 \\
\hline
\end{tabular}

which had an observed peak flow of $0.095 \mathrm{~mm} / 5 \mathrm{~min}$. In the other events, the maximum flows were close to $0.2 \mathrm{~mm} / 5 \mathrm{~min}$, and the calibration was considered efficient in adjusting the hydrograph peaks.

In relation to the lower flows, the lumped model corresponded adequately to three events (I, II and III), and in the others, it underestimated the minimum flows.

The calculated flow by the distributed version also showed good correspondence, maintaining the good peaks adjustment. There was a tendency to overestimate the flows of intermediate values (Figure 5).

The NASH values obtained by the D-Tank Model varied between 0.72 and 0.89 , and the RMSE from 0.01 to 0.026. Presenting a slight decrease in performance over the lumped model, the D-Tank Model still showed a satisfactory adjustment to the observed data. 
https://doi.org/10.5194/hess-2019-682

Preprint. Discussion started: 28 January 2020

(c) Author(s) 2020. CC BY 4.0 License.
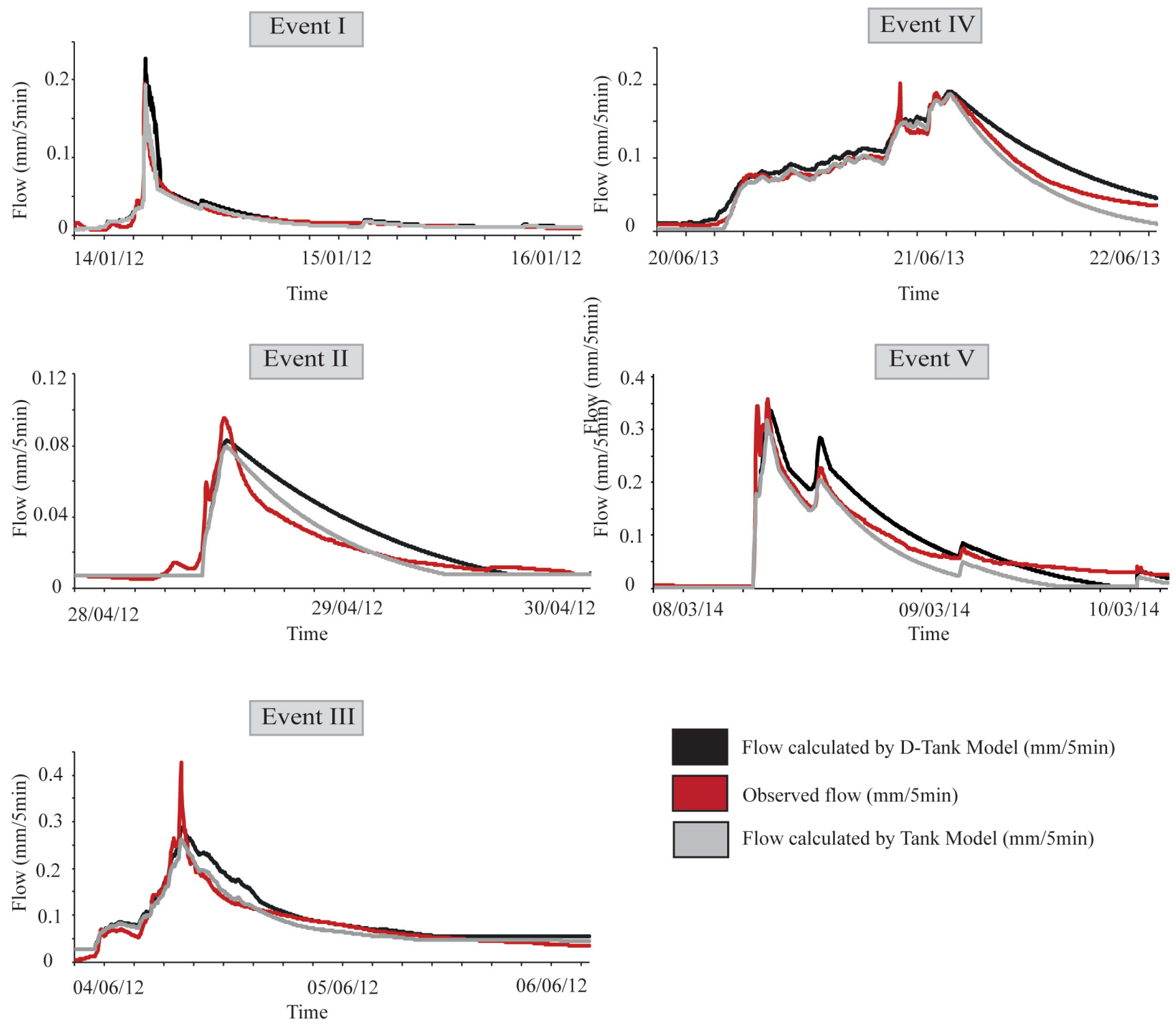

Figure 5. Calibration results with Tank Model and D-Tank Model.

\subsection{Validation}

The Tank Model simulation resulted in a satisfactory water balance for the two events analyzed, the RMSE close to zero and NASH very close to 1 (Table 6).

Figure 6 shows the predictive uncertainty of the events selected for validation. The uncertainty in validation increased in relation to the events selected for calibration. 
https://doi.org/10.5194/hess-2019-682

Preprint. Discussion started: 28 January 2020

(c) Author(s) 2020. CC BY 4.0 License.

Table 6. Calibration performance of the Tank Model (TM) and the D-Tank Model (DTM) evaluated with two objective functions for 5 events.

\begin{tabular}{c|cccc}
\hline & NASH & RMSE & NASH & RMSE \\
\hline Event & \multicolumn{2}{|c|}{ TM } & \multicolumn{2}{c}{ DTM } \\
\hline VI & 0.96 & 0.006 & 0.95 & 0.007 \\
VII & 0.92 & 0.010 & 0.72 & 0.020 \\
\hline
\end{tabular}
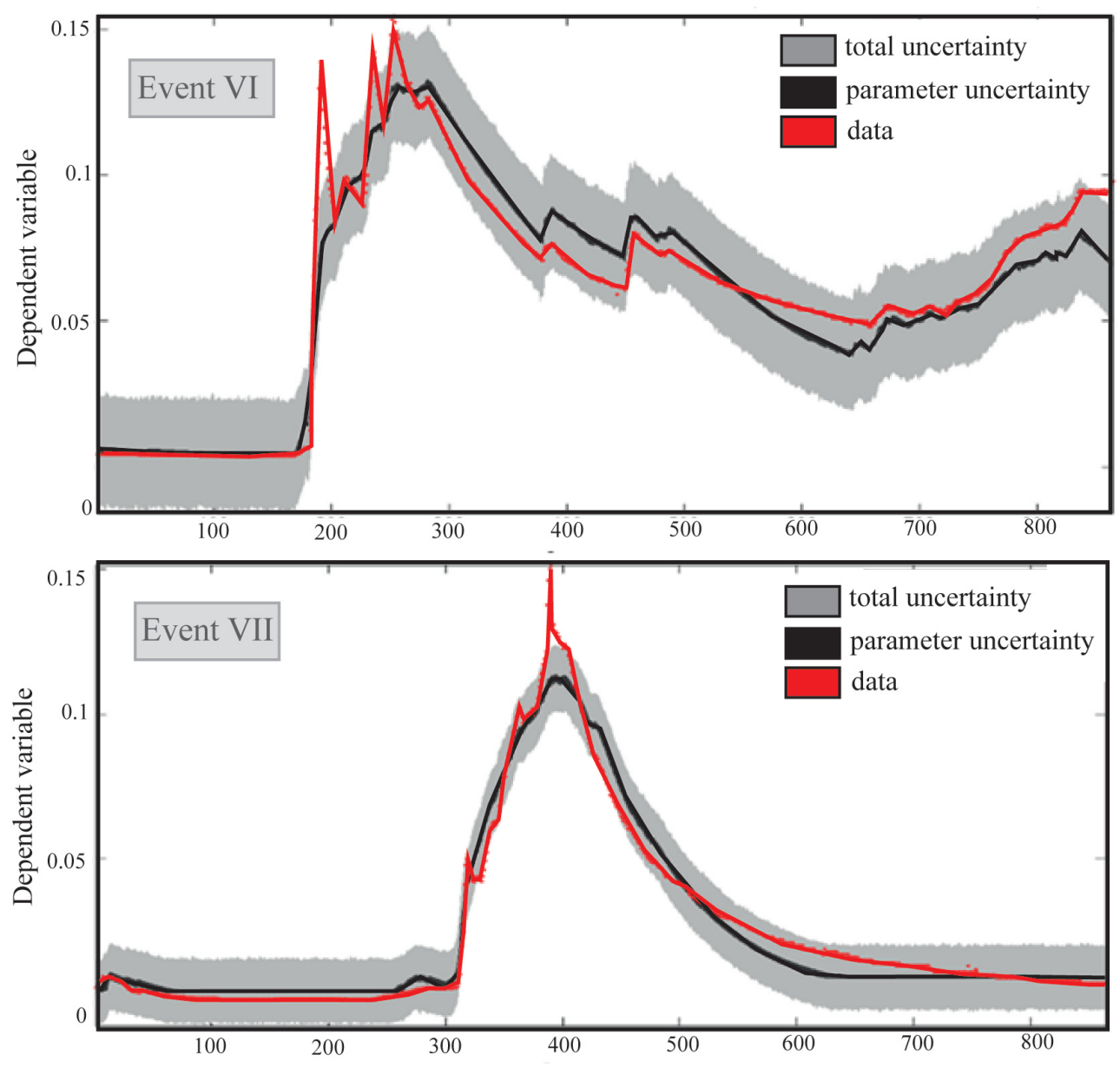

Figure 6. Uncertainty analysis for validation. Observed runoff series (red), 95\% uncertainty (light grey) and uncertainty associated with the values of the parameters (dark grey). 
https://doi.org/10.5194/hess-2019-682

Preprint. Discussion started: 28 January 2020

(c) Author(s) 2020. CC BY 4.0 License.

\section{Event VI}

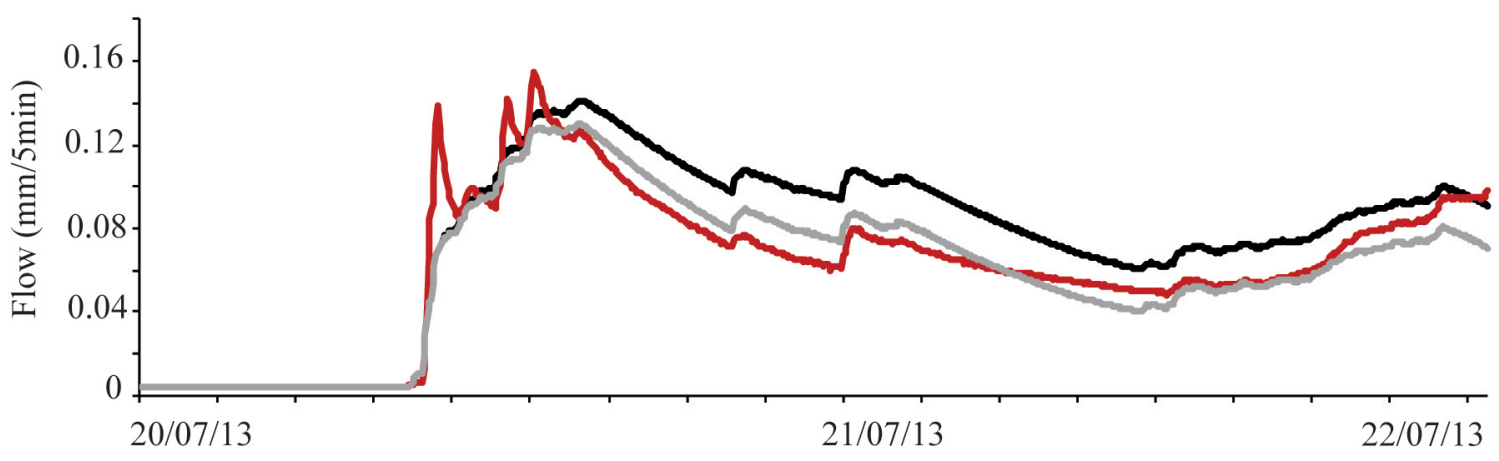

Time

\section{Event VII}

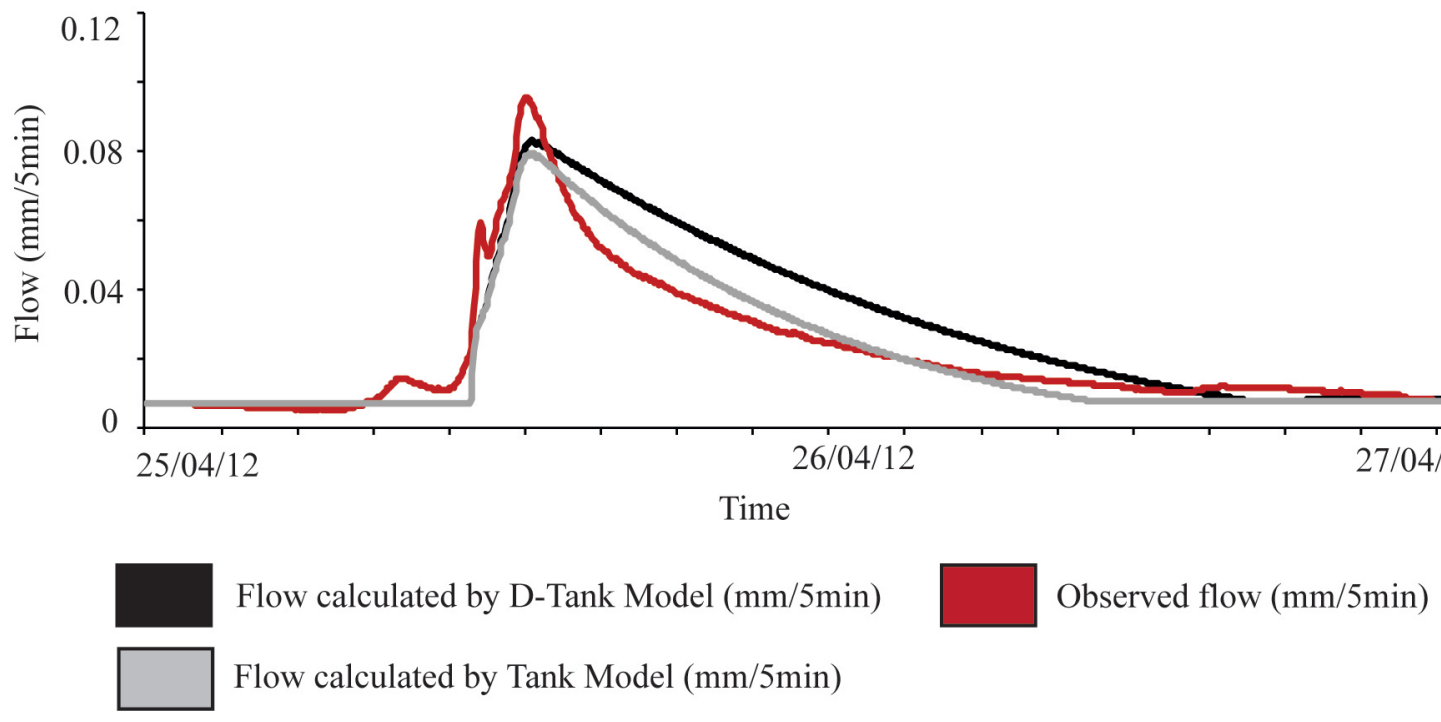

Figure 7. Validation results with Tank Model and D-Tank Model.

In the similar way, the D-Tank Model showed a good performance for the event VI, with RMSE also close to zero, and NASH close to 1 . In the event VII, there was a slightly high overestimation. The hydrographs representing the validation simulations are shown in Figure 7. The two versions (lumped and distributed) of Tank Model overestimated the flows after the peak in the event VII. It can be attributed to the used parameters, especially the infiltration coefficient and the baseflow coefficient, which could be probably overestimated. In the event VI, the Tank Model underestimated the maximum flow peak, which was enhanced by the D-Tank Model. 

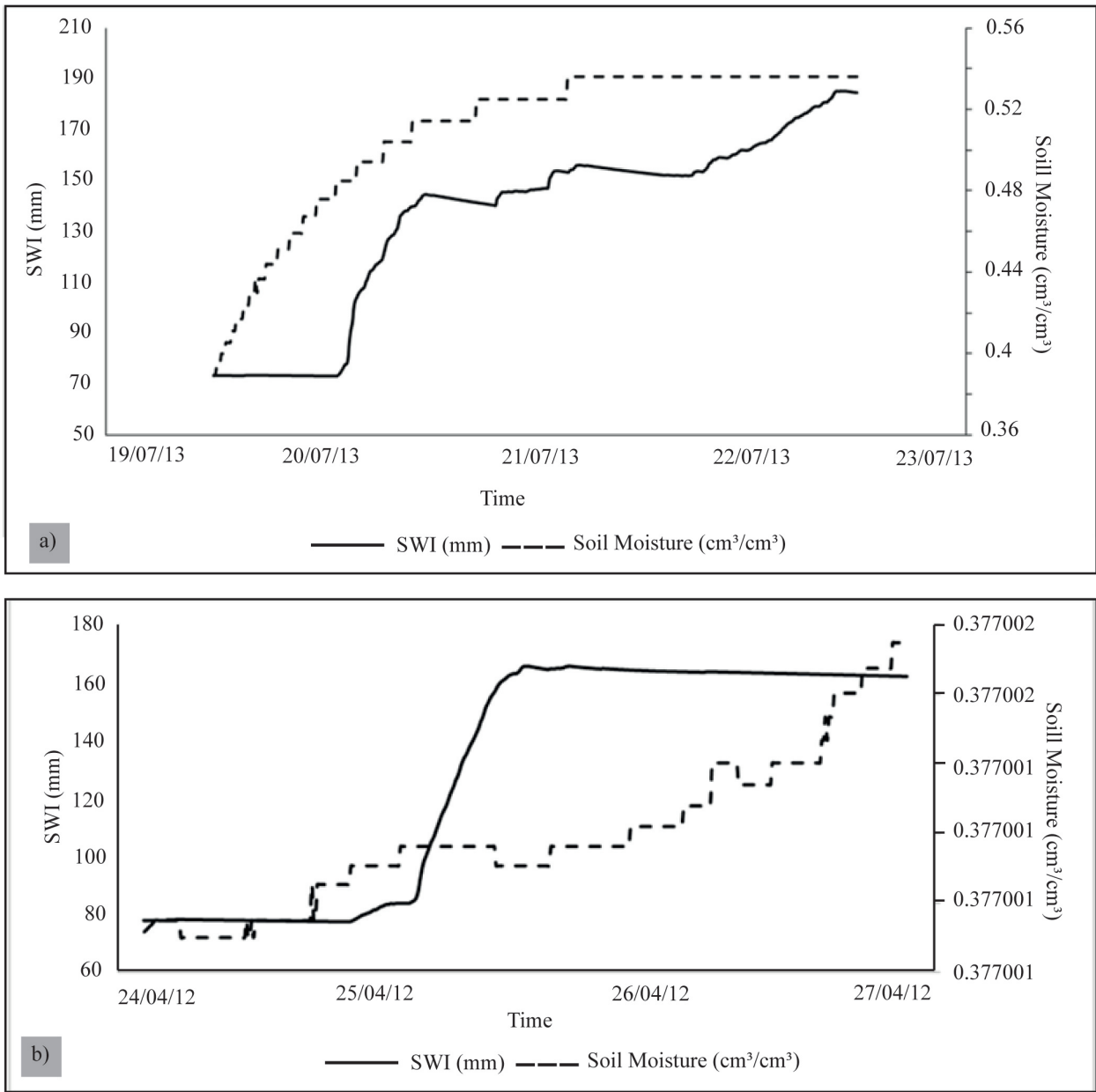

Figure 8. Relation between SWI and soil moisture calculated by the values obtained at the tensiometer: (a) A3 location at 10-cm depth during the Event VI; and (b) Z4 location at 30-cm depth, during the Event VII.

These results show that the distributed model was adequate for the application of the following steps (SWI generation and point comparison with the soil moisture values estimated from the tensiometer data).

\subsection{Soil Water Index}

Figure 8 shows two examples of behavior comparison between the SWI values obtained with the D-Tank Model simulation and the soil moisture values calculated by (a) the tensiometer A3 (10 cm depth) for the period July 20th to 22nd, 2013 (event VI) and (b), the tensiometer Z4 (30cm depth) for the period April 25 to 27th, 2012 (event VII). A visual analysis of the Figure 8 implies a satisfactory performance of the SWI gained from the D-Tank Model. 

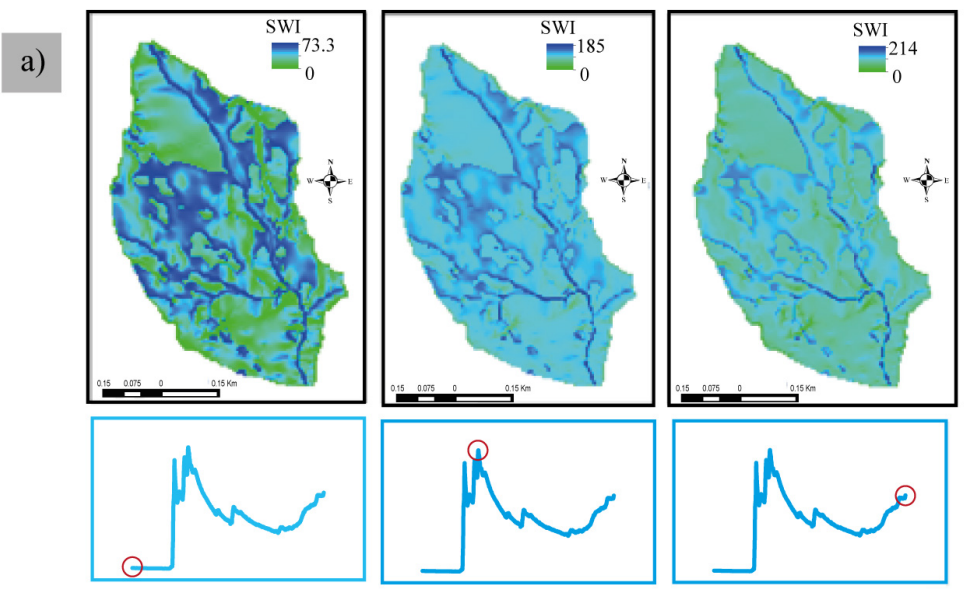

b)
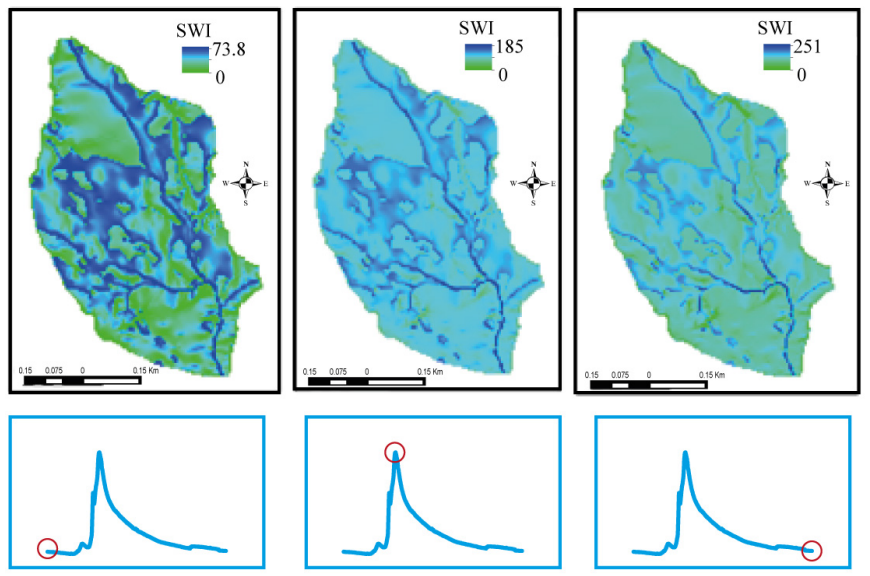

Figure 9. Spatial variation of the SWI values (mm) at 3 different moments of a hydrograph: (a) event VI; and (b) event VII.

The spatial variation of the SWI values at three different moments (the beginning of the event, the peak, and the last moment) of the two validation events VI and VII were elaborated in Figure 9. In both events the SWI behavior was very similar, especially at the beginning. It resulted from the fact that the initial storage heights of the two reservoirs were the same in both events. In the SWI maps related to the peak of the hydrograph, there is also a similarity between the values in the two events, which is consistent, since both had the same maximum flow rate in $0.15 \mathrm{~mm} / 5 \mathrm{~min}$. In general, the points of the highest SWI values were located along the drainage network. However, high SWI values were also observed at certain points of hillslopes. Furthermore, the SWI values were larger in the area closer to the basin exit, which is reasonable. 

higher, reaching $251 \mathrm{~mm}$, while most of the basin was showing its values of up to $193 \mathrm{~mm}$. In the event VII, the maximum value was slightly smaller $(214 \mathrm{~mm})$, however the remaining area of the basin was wetter, represented by a SWI of $205 \mathrm{~mm}$.

Between the two events, the spatial behavior of the SWI was similar, where wetter areas at any time kept their wetness under other circumstances (Figure 8). In relation to the upstream section, the SWI values in the section closer to the outlet were slightly larger, which is coherent.

Vachaud et al. (1985) observed this behavior of soil moisture and proposed the concept of temporal stability of soil moisture, i.e., there is a high probability that a moist condition for a moment will remain itself at other times. By using geostatistical tools, Gonçalves et al. (1999) observed the persistence in time of moisture distributions. This is an interesting result because the confirmation of the temporal stability of the soil moisture distribution allows reducing the sampling number for monitoring or estimating the soil water storage.

The spatial variation of the SWI can be observed also in Figure 10, where two cross sections were selected for SWI evaluation at the peak of the event VI. In the cross-section 1, there is a 60-m elevation difference between the highest point and the river, although these points are about 200-m distant.

The SWI value in this profile was almost constant, with a slight increase of $20 \mathrm{~mm}$ in the point located in the river. In the cross section 2, the SWI behavior in a profile closer to the outlet is presented. With a difference of $30 \mathrm{~m}$ of elevation between the highest point and the river, but distant from one another only by $80 \mathrm{~m}$, the SWI variation throughout the section was slightly larger, and, as expected, the highest SWI value occurred at the river.

\subsection{Linear Correlation between SWI and Soil Moisture}

For linear correlation analysis between SWI and the only measured values of soil moisture, the present study used only the tensiometers' data which were considered minimally coherent in relation to the precipitation of the event. Therefore, the tensiometer of cell A12 was excluded from all the comparisons.

In the event VI, a strong correlation between the calculated SWI and the soil moisture in all the analyzed cells and depths. They are all below 0.7 (Table 7). Figure 11 shows the linear relation between SWI and Soil Moisture calculated by the tension of to the sensor A3, tensiometer location at $10 \mathrm{~cm}$ of depth during the Event VI.

Significant correlations between the SWI and the soil moisture were also obtained for the event VII (Table 8). However, in this event, those correlations were more significant in the uppermost layers of the soil. It can be said that all the analyses demonstrated that a SWI behavior is similar to that of the soil moisture.

TWI and HAND were generated (Figure 12) to be used as soil moisture indicators. Both maps were compared to SWI results (Figure 9) in order to verify a correlation between them. A visual analysis permits to verify the similarity of spatial behavior between TWI and SWI maps. The HAND topology also shows the similarity with TWI (the lower values are located in the areas more close to the drainage, that are usually more moist). 


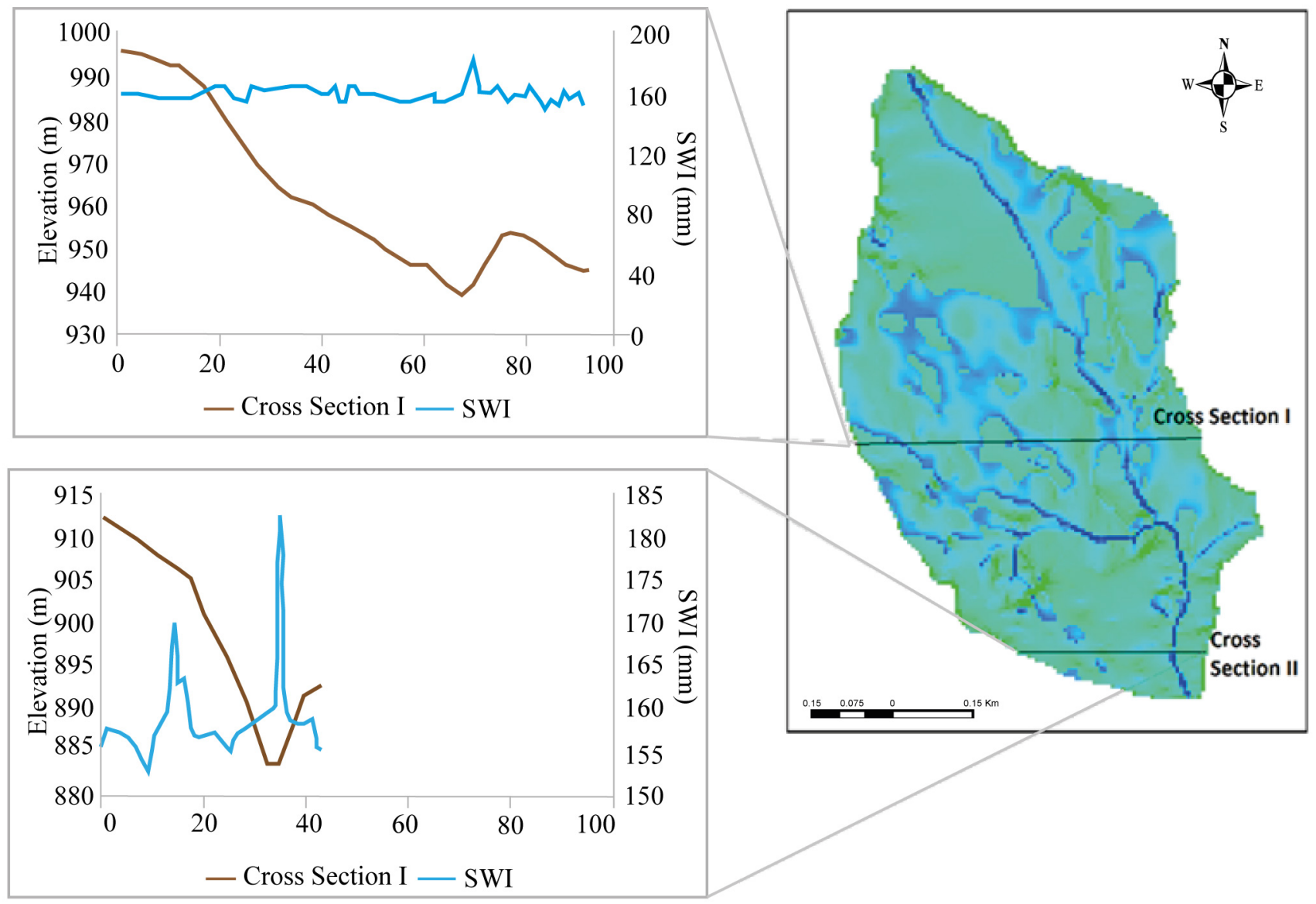

Figure 10. Variation of SWI in two transverse sections of the basin at the hydrograph peak for event VI.

The results of the correlation analysis show the high correlation of SWI with the TWI values (in both events and in all 3 different hydrograph moments) (Table 9). HAND presented smaller values of $r$, but still presented significant correlation with SWI.

The correlation between SWI and TWI could be explained for the structure of the D-Tank Model, where similarly as the TWI, the accumulated flow has a determinant influence on the generated results. Thus, it can be said that SWI has a major relation with flow accumulation and slope than the vertical distance to the stream. 


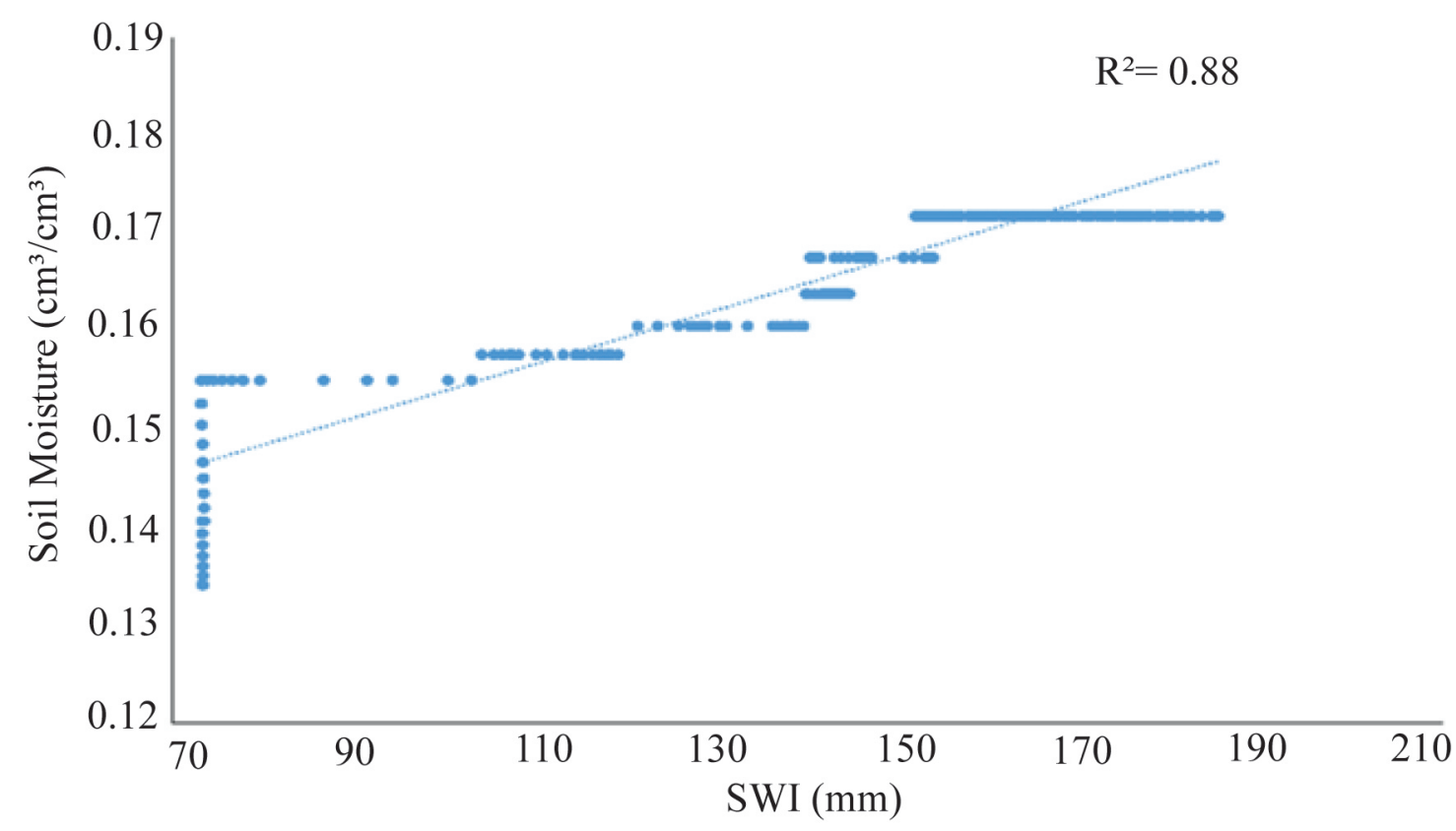

Figure 11. Linear relation between SWI and Soil Moisture calculated with the values obtained at the tensiometer A3 location at $10 \mathrm{~cm}$ of depth during the Event VI.

\subsection{Linear Correlation of Soil-Moisture Spatial Distribution with SWI, TWI and HAND}

For spatial analysis of linear correlation between the Soil Moisture and SWI, TWI and HAND, the present study used only the soil moisture data estimated with the tensiometers located at 30-cm depth, because of the two reasons: (i) these were the sensors that generated more coherent results at all the analyzed events; and (ii) Ehret (2014) reported that the mean moisture of the first 30-cm soil layer was a robust indicator of the slopes initial conditions prior to a rainfall event.

Several studies used geostatistics for estimate soil moisture patterns from point observations (Bardossy and Lehmann,1998; Western et al.,1998; Western and Bloschl,1999; Western et al.,1999; Perry and Niemann,2008; Yang et al.,2017). The Inverse Distance Weighting (IDW) method was used for interpolating the soil moisture values calculated by tensiometer information, and the distributed soil moisture maps were generated. However, in this case, only the covered area by the sensors was treated because of the limitation of this method (Figure 13).

The different patterns of spatial distribution of soil moisture can be observed between two analyzed events (Event VI and Event VII). Though the total values of rainfall of the Event VI and VII were similar (104.59 $\mathrm{mm}$ and $139.12 \mathrm{~mm}$, respectively), the values of the initial soil water content were slightly different $\left(0.55 \mathrm{~cm}^{3} / \mathrm{cm}^{3}\right.$ in Event VI and $0.41 \mathrm{~cm}^{3} / \mathrm{cm}^{3}$ in Event 
Table 7. Values of $\mathrm{r}$ for the comparison between SWI and soil moisture for Event VI

\begin{tabular}{cccccccc}
\hline \multicolumn{7}{c}{ Sensor Depth (m) - Configuration I } \\
\hline & 0.1 & 0.2 & 0.3 & 0.4 & 0.6 & 0.7 & 0.9 \\
\hline A4 & - & 0.80 & 0.80 & 0.90 & 0.90 & - & - \\
A3 & 0.88 & - & 0.60 & 0.83 & 0.65 & - & 0.65 \\
B3 & - & 0.60 & 0.70 & 0.70 & 0.80 & 0.80 & 0.90 \\
B4 & - & 0.80 & 0.90 & - & - & 0.90 & 0.90 \\
Z3 & - & 0.70 & 0.70 & - & - & 0.83 & - \\
Z4 & - & - & 0.70 & 0.80 & 0.90 & 0.90 & 0.80 \\
\hline & & Sensor Depth (m) - Configuration II & \\
\hline & 0.1 & 0.3 & 0.4 & $0.1 *$ & $0.3 *$ & $0.4 *$ & \\
\hline B12 & - & 0.90 & 0.80 & 0.80 & 0.90 & 0.90 & \\
Z12 & - & 0.90 & 0.90 & - & 0.90 & 0.90 & \\
\hline
\end{tabular}

Table 8. Values of $\mathrm{r}$ for the comparison between SWI and soil moisture for Event VII

\begin{tabular}{ccccccccc}
\hline \multicolumn{7}{c}{ Sensor Depth (m) - Configuration I } \\
\hline & 0.1 & 0.2 & 0.3 & 0.4 & 0.6 & 0.7 & 0.9 \\
\hline A4 & 0.60 & 0.90 & 0.90 & 0.30 & - & 0.30 & - \\
A3 & 0.80 & 0.90 & 0.70 & 0.90 & 0.40 & 0.40 & \\
B3 & 0.60 & 0.60 & 0.70 & - & - & - & - \\
B4 & 0.80 & - & 0.80 & 0.80 & - & 0.40 & - \\
Z3 & 0.30 & - & 0.90 & - & - & - & 0.9 \\
Z4 & 0.50 & 0.90 & 0.90 & 0.80 & - & 0.70 & - \\
\hline & Sensor Depth (m) & Configuration II & \\
\hline B12 & 0.60 & 0.95 & - & 0.60 & - & - & \\
Z12 & - & 0.60 & - & 0.80 & - & 0.90 & \\
\hline
\end{tabular}

VII), which might result in the differences in the peak flow between these events $(0.15 \mathrm{~mm}$ in Event VI and $0.09 \mathrm{~mm}$ in Event VII). Zehe et al. (2007) and Uber et al. (2018) found significant effects of initial soil moisture condition on discharge values. 
https://doi.org/10.5194/hess-2019-682

Preprint. Discussion started: 28 January 2020

(c) Author(s) 2020. CC BY 4.0 License.
Hydrology and Earth System Sciences Discussions

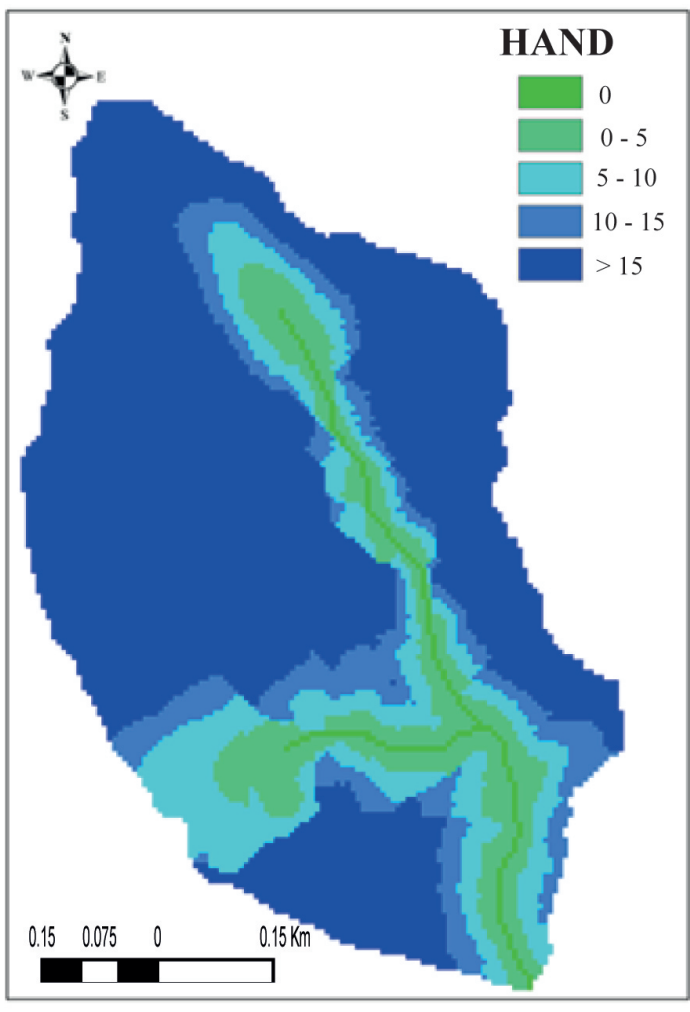

a)

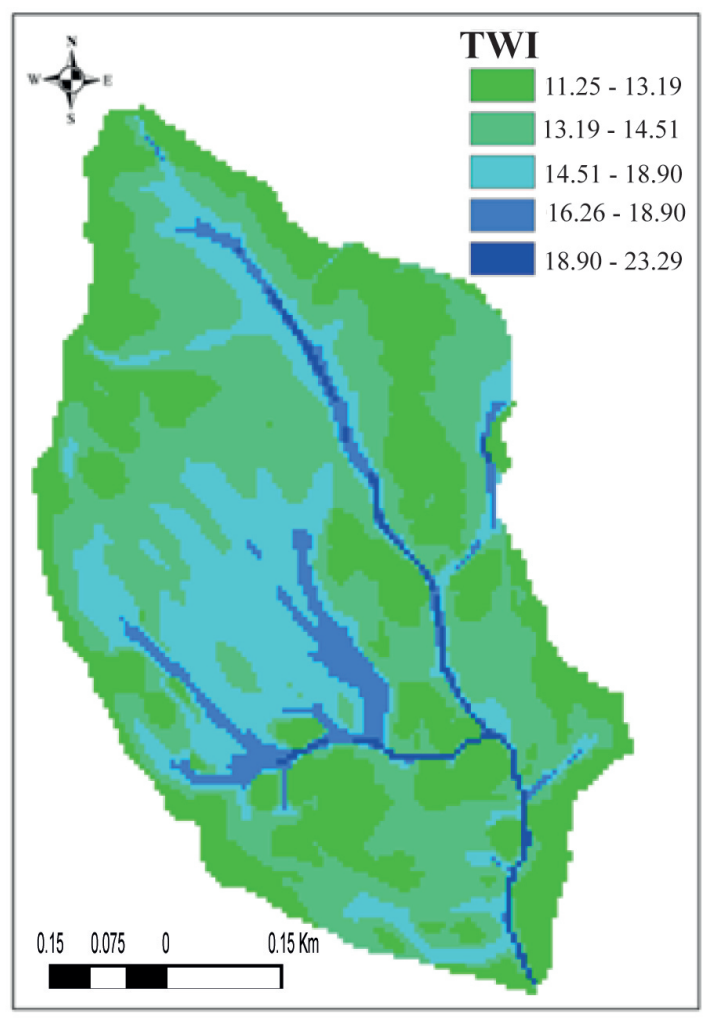

b)

Figure 12. Spatial distribution in the study basin: (a) HAND topology; and (b) TWI.

Table 9. Values of $\mathrm{r}$ for the comparison between the SWI, TWI and HAND

\begin{tabular}{ccccccc}
\hline & \multicolumn{3}{c}{ Event VI } & \multicolumn{3}{c}{ Event VII } \\
\hline & I & II & III & I & II & III \\
\hline TWI & 0.88 & 0.88 & 0.88 & 0.88 & 0.88 & 0.87 \\
HAND & 0.62 & 0.63 & 0.62 & 0.62 & 0.63 & 0.62 \\
\hline
\end{tabular}

Furthermore, Zehe and Sivapalan (2009) demonstrated how the initial soil moisture condition influenced on the infiltration process and consequent runoff generation.

The distribution features of the soil moisture had high correlations with SWI, TWI, and HAND (Table 10). 
https://doi.org/10.5194/hess-2019-682

Preprint. Discussion started: 28 January 2020

(C) Author(s) 2020. CC BY 4.0 License.
Hydrology and

Earth System

Sciences

Discussions

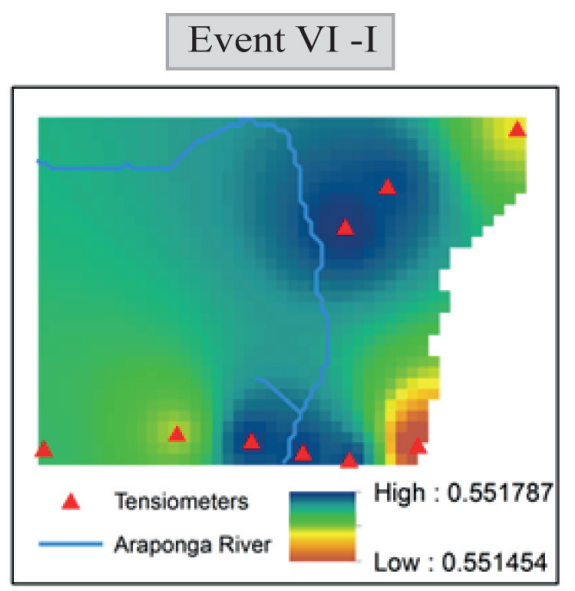

\section{Event VII -I}

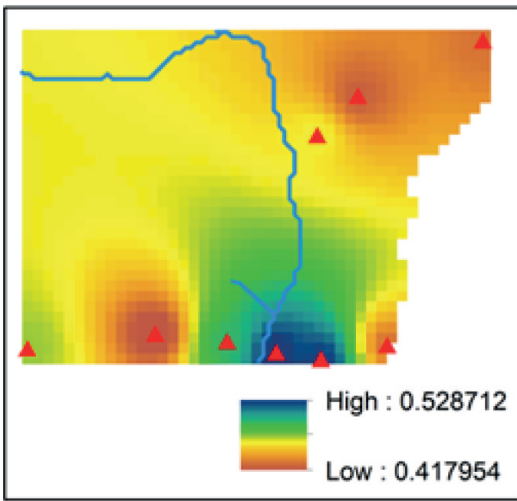

Event VI -II

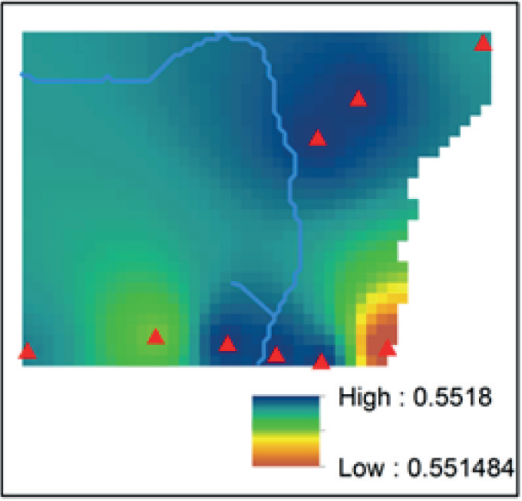

Event VII -II

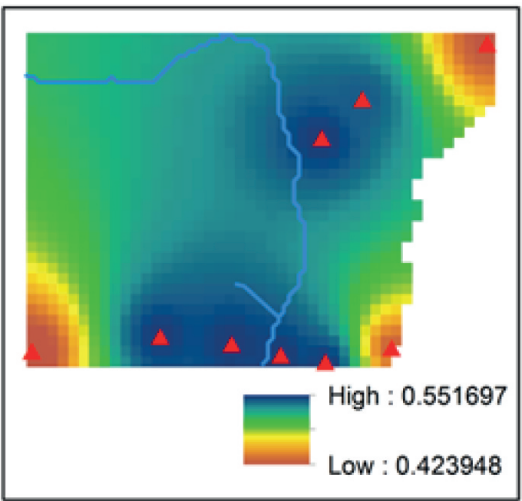

Event VI -III

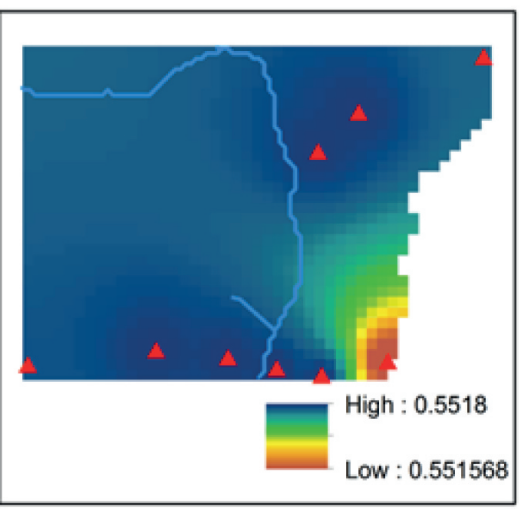

Event VII -III

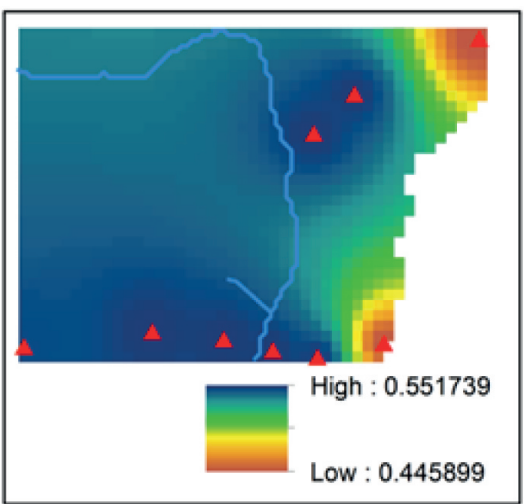

Figure 13. Soil Moisture $\left(\mathrm{cm}^{3} / \mathrm{cm}^{3}\right)$ at $30-\mathrm{cm}$ depth, calculated with IDW method, for three different stages of the events VI and VII.

Table 10. Values of $\mathrm{r}$ for the comparison of the distributed Soil Moisture with SWI, TWI and HAND

\begin{tabular}{ccccccc}
\hline & \multicolumn{3}{c}{ Event VI } & \multicolumn{3}{c}{ Event VII } \\
\hline & I & II & III & I & II & III \\
\hline SWI & 0.95 & 0.95 & 0.95 & 0.95 & 0.95 & 0.95 \\
TWI & 0.90 & 0.90 & 0.90 & 0.90 & 0.90 & 0.90 \\
HAND & 0.84 & 0.84 & 0.84 & 0.84 & 0.84 & 0.84 \\
\hline
\end{tabular}

According to Western et al. (1999), soil moisture patterns depend on different topographic properties at different times.The authors found that TWI can explain soil moisture variability at catchment scale. Minet et al. (2011) analyzed soil moisture 
https://doi.org/10.5194/hess-2019-682

Preprint. Discussion started: 28 January 2020

(c) Author(s) 2020. CC BY 4.0 License.

patterns in terms of runoff response, and concluded that the use of TWI for evaluating the soil moisture pattern is a suitable technique. Observing Table 10 more in detail, it can be said that the SWI generated by D-Tank Model performed slightly better than TWI. Hence, the use of SWI could be more recommended for the soil moisture representation. Loritz et al. (2019) discussed hydrologic similarity in different catchments comparing TWI and HAND performance, and concluded that despite the similarities between these indices, they represent different hydrological aspects, where the modified-HAND version performed better than TWI and HAND approaches. Contrary to their study, the present study showed that HAND was the worst index to represent soil moisture patters.

315 Downer and Ogden (2003) also used a distributed conceptual model to estimate soil moisture, concluding that physicallybased hydrologic models can be used to make predictions of peak discharge and soil moisture. The present study can infer that a distributed conceptual hydrological model can be used to predict soil moisture patterns in catchment scale.

\section{Conclusions}

By using the D-infinity method of (Tarboton, 1997), the present study constructed a distributed version of Tank Model and called it D-Tank Model. Adopting the SWI proposed by Okada et al. (2001), the D-Tank Model was applied in order to evaluate the soil moisture distribution in the Araponga river basin in the rural area of Rio Negrinho municipality of the Santa Catarina state, southern Brazil. Then the performance of the D-Tank Model and the spatially-distributed SWI values were verified with rainfall, discharge and soil moisture data.

Based on the obtained results, it can be concluded that the D-Tank Model had satisfactory performance for the studied period. Hydrographs between the observed and calculated flow showed a good fitting. The spatially distributed values of the SWI, generated from the D-Tank Model, performed also satisfactorily, representing well the spatial variation of the water storage within the basin, which were qualitatively confirmed with the soil moisture data. Even compared with TWI and HAND, the SWI values presented better fit with the values of linear correlation between the analyzed maps.

The spatially-distribution analysis of the soil moisture was used to validate SWI, which shows good correlation. Thus, the use of SWI could be recommended for the soil moisture representation. However, the D-Tank Model and its derived SWI values should be checked with other basins which are different from the Araponga basin in terms of the basin size, forest type, land-use, among others.

Code and data availability. The full analysis scripts are published on Github (https://github.com/mvsofia/dtankmodel). The data is available upon request. 
https://doi.org/10.5194/hess-2019-682

Preprint. Discussion started: 28 January 2020

(C) Author(s) 2020. CC BY 4.0 License.

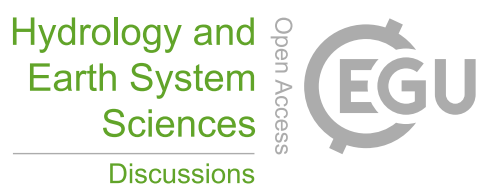

AM supplied the field descriptions, and one of the figures. Structure and language of the manuscript was revised and improved by AM and MK.

Competing interests. The authors declare to have no competing interests 


\section{References}

Alvares, C., Stape, J., Sentelhas, P., Gonçalves, J., and Sparovek, G.: Köppen's climate classification map for Brazil, Meteorologische Zeitschrift, 22, 711-728, https://doi.org/10.1127/0941-2948/2013/0507, 2013.

Beven, K. J. and Kirkby, M. J.: A physically based, variable contributing area model of basin hydrology, Hydrological Sciences Bulletin, 24, 43-69, https://doi.org/10.1080/02626667909491834, 1979.

Brocca, L., Ciabatta, L., Massari, C., Camici, S., and Tarpanelli, A.: Soil moisture for hydrological applications: open questions and new opportunities, Water, 9, 140, 2017.

Bardossy, A. and Lehmann, W.: Spatial distribution of soil moisture in a small catchment. Part 1: geostatistical analysis, Journal of Hydrology, 206, 1 - 15, https://doi.org/https://doi.org/10.1016/S0022-1694(97)00152-2, 1998.

Carrão, H., Russo, S., Guadalupe, S., and Barbosa, P.: An empirical standardized soil moisture index for agricultural drought assessment from remotely sensed data, International Journal of Applied Earth Observation and Geoinformation, 48, 74-84, 2016.

Castillo, V., Gomez-Plaza, A., and Martinez-Mena, M.: The role of antecedent soil watercontent in the runoff response of semiarid catchments: a simulation approach, Journal of Hydrology, 284, 114-130, 2003.

Chen, C., Saito, H., and Oguchi, T.: Analyzing rainfall-induced mass movements in Taiwan using the soil water index, Landslides, 14, 1031-1041, 2017.

Chen, R.-S., Pi, L.-C., and Huang, Y.-Y.: Analysis of rainfall-runoff relation in paddy fields by diffusive tank model, Hydrological Processes, 17, 2541-2553, 2003.

Chen, S.-C., Tsai, C.-W., Chen, C.-Y., and Chen, M.-C.: Soil water index applied as a debris flow warning-reference based on a tank model, Journal of Chinese Soil and Water Conservation, 44, 131-143, 2013.

Cunha David, P., de Oliveira, D., Grison, F., Kobiyama, M., and Chaffe, P.: Systematic increase in model complexity helps to identify dominant streamflow mechanisms in two small forested basins, Hydrological Sciences Journal, 64, https://doi.org/10.1080/02626667.2019.1585858, 2019.

Doorenbos, J. and Pruitt, W.: Guidelines for Predicting Crop Water Requirements, FAO Irrigation and Drainage, $24,1977$.

Downer, C. W. and Ogden, F. L.: Prediction of runoff and soil moistures at the watershed scale: Effects of model complexity and parameter assignment, Water Resources Research, 39, https://doi.org/10.1029/2002WR001439, 2003.

Ehret, U.: Dynamical grouping and representative computation: a new approach to reduce computational efforts in distributed, physically based modeling on the lower mesoscale, 2014.

Entin, J. K., Robock, A., Vinnikov, K. Y., Hollinger, S. E., Liu, S., and Namkhai, A.: Temporal and spatial scales of observed soil moisture variations in the extratropics, Journal of Geophysical Research: Atmospheres, 105, 11 865-11 877, https://doi.org/10.1029/2000JD900051, 2000.

Franchini, M. and Pacciani, M.: Comparative analysis of several conceptual rainfall-runoff models, Journal of Hydrology, 122 , 161 - 219, https://doi.org/https://doi.org/10.1016/0022-1694(91)90178-K, 1991.

Gharari, S., Hrachowitz, M., Fenicia, F., and Savenije, H.: Hydrological landscape classification: Investigating the performance of HAND based landscape classifications in a central European meso-scale catchment, Hydrology and Earth System Sciences, 15, 3275-3291, https://doi.org/10.5194/hess-15-3275-2011, 2011.

Gonçalves, A. C. A., Folegatti, M. V., and Silva, A. P.: Estabilidade temporal da distribuição espacial da umidade do solo em área irrigada por pivô central, Revista Brasileira de Ciência do Solo, 23, 155 - 164, 1999. 
https://doi.org/10.5194/hess-2019-682

Preprint. Discussion started: 28 January 2020

(c) Author(s) 2020. CC BY 4.0 License.

Grillakis, M. G., Koutroulis, A. G., Komma, J., Tsanis, I. K., Wagner, W., and Blöschl, G.: Initial soil moisture effects on flash flood generation - A comparison between basins of contrasting hydro-climatic conditions, Journal of Hydrology, 541, 206-217, https://doi.org/10.1016/j.jhydrol.2016.03.007, 2016.

Gumuzzio, A., Brocca, L., Sanchez, N., González-Zamora, , and Martínez-Fernández, J.: Comparison of SMOS, modelled and in situ long-term soil moisture series in the NW of Spain, Hydrological Sciences Journal, 61, 2610-2625, https://doi.org/10.1080/02626667.2016.1151981, 2016.

Huang, W., Nakane, K., Matsuura, R., and Matsuura, T.: Distributed tank model and GAME reanalysis data applied to the simulation of runoff within the Chao Phraya River Basin, Thailand, Hydrological Processes, 21, 2049 - 2060, https://doi.org/10.1002/hyp.6710, 2007.

Ishihara, Y. and Kobatake, S.: Runoff model for flood forecasting, Bulletin of Disaster Prevention Research Institute, 29, $27-43,1979$.

Jun, B.-H.: Numerical simulation of the topographical change in Korea Mountain area by intense rainfall and consequential debris flow, Advances in Meteorology, 2016, 1-11, https://doi.org/10.1155/2016/9363675, 2016.

Kato, T.: Development of a water quality tank model classified by land use for nitrogen load reduction scenarios, Paddy and Water Environment, 3, 21-27, https://doi.org/10.1007/s10333-005-0069-4, 2005.

Kato, T., Kuroda, H., and Nakasone, H.: A distributed water quality tank model for nitrogen load reduction by artificial wetlands, Journal of Water and Environment Technology, 3, 235-242, https://doi.org/10.2965/jwet.2005.235, 2005.

Kerr, Y., Philippe, W., Wigneron, J.-P., Martinuzzi, J.-M., Font, J., and Berger, M.: Soil moisture retrieval from space: The soil moisture and ocean salinity (SMOS) Mission, Geoscience and Remote Sensing, IEEE Transactions on, 39 , 1729 - 1735, https://doi.org/10.1109/36.942551, 2001.

Kim, S.: Characterization of annual soil moisture response pattern on a hillslope in Bongsunsa Watershed, South Korea, Journal of Hydrology, s 448-449, 100-111, https://doi.org/10.1016/j.jhydrol.2012.04.030, 2012.

Kobaishi, S. and Suzuki, M.: The critical rainfall (danger index) for disasters caused by debris flows and slope failures, IAHS Publications, $165,201-211,1987$.

Kohler, M. and Linsley, R.: Predicting the runoff from storm rainfall, Weather Bureau Research Papers, 34, 1951.

Laloy, E. and Vrugt, J.: High-dimensional posterior exploration of hydrologic model using multiple-try DREAM(ZS) and high-performance computing, Water Resources Research, 50, https://doi.org/10.1029/2011WR010608, 2012.

Lee, Y. and Singh, V.: Tank Model for Sediment Yield, Water Resources Management, 19, 349-362, https://doi.org/10.1007/s11269-0057998-y, 2005.

Linde, N. and Vrugt, J.: Distributed Soil Moisture from Crosshole Ground-Penetrating Radar Travel Times using Stochastic Inversion, Vadose Zone Journal, 12, 0, https://doi.org/10.2136/vzj2012.0101, 2013.

Lindner, E. and Kobiyama, M.: Proposal of Tank Moisture Index to predict floods and droughts in Peixe River watershed, Brazil, IAHS Publications, 331, 314-323, 2009.

Loritz, R., Kleidon, A., Jackisch, C., Westhoff, M., Ehret, U., Gupta, H., and Zehe, E.: A topographic index explaining hydrological similarity by accounting for the joint controls of runoff formation, Hydrology and Earth System Sciences, 23, 3807-3821, https://doi.org/10.5194/hess-23-3807-2019, 2019.

Mälicke, M., Hassler, S. K., Blume, T., Weiler, M., and Zehe, E.: Soil moisture: variable in space but redundant in time, Hydrology and Earth System Sciences Discussions, 2019, 1-28, https://doi.org/10.5194/hess-2019-574, https://www.hydrol-earth-syst-sci-discuss.net/ hess-2019-574/, 2019. 
https://doi.org/10.5194/hess-2019-682

Preprint. Discussion started: 28 January 2020

(c) Author(s) 2020. CC BY 4.0 License.

Manfreda, S., Samela, C., Gioia, A.and Consoli, G., Iacobellis, V., Giuzio, L., Cantisani, A., and Sole, A.: Flood-prone areas assessment using linear binary classifiers based on flood maps obtained from 1D and 2D hydraulic models, Natural Hazards, 79, 735-754, 2015.

Matlan, S., Abdullah, S., Alias, R., and Mukhlisin, M.: Effect of working rainfall and soil water index on slope stability in Ranau, Sabah, International Journal of Civil Engineering and Technology, 9, 1331-1441, 2018.

Metzen, D., Sheridan, G., Benyon, R., Bolstad, P. V., Griebel, A., and Lane, P.: Spatio-temporal transpiration patterns reflect vegetation structure in complex upland terrain, Science of the Total Environment, 694, https://doi.org/10.1016/j.scitotenv.2019.07.357, 2019.

Minet, J., Laloy, E., Lambot, S., and Vanclooster, M.: Effect of high-resolution spatial soil moisture variability on simulated runoff response using a distributed hydrologic model, Hydrology and Earth System Sciences, 15, 1323-1338, https://doi.org/10.5194/hess-15-1323-2011, https://www.hydrol-earth-syst-sci.net/15/1323/2011/, 2011.

Mota, A.: Mecanismo de geração de vazão em pequena bacia experimental do bioma Mata Atlântica, Ph.D. thesis, 2017.

Mota, A., Grison, F., Giglio, J., and Kobiyama, M.: Instalação de uma pequena bacia experimental florestal: Estudo de caso da bacia do Rio Araponga, Revista Brasileira de Engenharia Sanitária e Ambiental, 22, 73-80, 2017.

Mukhlisin, M., Matlan, S., Ahlan, M., and Taha, M.: Analysis of rainfall effect to slope stability in Ulu Klang, Malaysia, Jurnal Teknologi, 72, 15-21, 2015.

Nardi, F., Vivoni, E. R., and Grimaldi, S.: Investigating a floodplain scaling relation using a hydrogeomorphic delineation method, Water Resources Research, 42, https://doi.org/10.1029/2005WR004155, 2006.

430 Nash, J. and Sutcliffe, J.: River flow forecasting through conceptual models part I - A discussion of principles, Journal of Hydrology, 10, 282 - 290, https://doi.org/https://doi.org/10.1016/0022-1694(70)90255-6, 1970.

Nie, W., Krautblatter, M., Leith, K., Thuro, K., and Festl, J.: A modified tank model including snowmelt and infiltration time lags for deep-seated landslides in alpine environments (Aggenalm, Germany), Natural Hazards and Earth System Sciences, 17, 1595-1610, https://doi.org/10.5194/nhess-17-1595-2017, https://www.nat-hazards-earth-syst-sci.net/17/1595/2017/, 2017.

Okada, K., Makihara, Y., Shimpo, A., Nagata, K., , Kunnitsugu, M., and Saito, M.: Soil Water Index, Tenki, 47, 36-41, 2001.

Oku, Y., Yoshino, J., Takemi, T., and Ishikawa, H.: Assessment of heavy rainfall-induced disaster potential based on an ensemble simulation of Typhoon Talas (2011) with controlled track and intensity, Natural Hazards and Earth System Sciences, 14, 2699-2709, https://doi.org/10.5194/nhess-14-2699-2014, https://www.nat-hazards-earth-syst-sci.net/14/2699/2014/, 2014.

Paulik, C., Dorigo, W., Wagner, W., and Kidd, R.: Validation of the ASCAT Soil Water Index using in situ data from the International Soil Moisture Network, International Journal of Applied Earth Observation and Geoinformation, 30, 1-8, https://doi.org/10.1016/j.jag.2014.01.007, 2014.

Pellarin, T., Louvet, S., Gruhier, C., Quantin, G., and Legout, C.: A simple and effective method for correcting soil moisture and precipitation estimates using AMSR-E measurements, Remote Sensing of Environment, 136, 28-36, https://doi.org/10.1016/j.rse.2013.04.011, 2013.

Perry, M. A. and Niemann, J. D.: Generation of soil moisture patterns at the catchment scale by EOF interpolation, Hydrology and Earth System Sciences, 12, 39-53, https://doi.org/10.5194/hess-12-39-2008, 2008.

Radula, M., Szymura, T., and Szymura, M.: Topographic wetness index explains soil moisture better than bioindication with Ellenbergs indicator values, Ecological Indicators, 85, 172-179, https://doi.org/10.1016/j.ecolind.2017.10.011, 2018.

Rahmati, O., Kornejadi, A., Samadi, M., Nobre, A., and Melesse, A.: Development of an automated GIS tool for reproducing the HAND terrain model, Environmental Modelling Software, 102, 1-12, 2018.

450 Rennó, C. D., Nobre, A. D., Cuartas, L. A., Soares, J. V., Hodnett, M. G., and Tomasella, J.: HAND, a new terrain descriptor using SRTMDEM: Mapping terra-firme rainforest environments in Amazonia, Remote Sensing of Environment, 112, 3469-3481, 2008. 
https://doi.org/10.5194/hess-2019-682

Preprint. Discussion started: 28 January 2020

(c) Author(s) 2020. CC BY 4.0 License.

Saito, H. and Matsuyama, H.: Catastrophic Landslide Disasters Triggered by Record-Breaking Rainfall in Japan: Their Accurate Detection with Normalized Soil Water Index in the Kii Peninsula for the Year 2011, SOLA, 8, 81-84, https://doi.org/10.2151/sola.2012-021, 2012.

Saito, H. and Matsuyama, H.: Probable Hourly Precipitation and Soil Water Index for 50-yr Recurrence Interval over the Japanese Archipelago, SOLA, 11, 118-123, https://doi.org/10.2151/sola.2015-028, 2015.

Saldanha, C., Tucci, C., Wood, E., and Li, H.: Previsão de longo prazo da umidade do solo no rio Uruguai, Revista Brasileira de Recursos Hidricos, 17, 39-47, 2012.

Saleem, J. A. and Salvucci, G. D.: Comparison of Soil Wetness Indices for Inducing Functional Similarity of Hydrologic Response across Sites in Illinois, Journal of Hydrometeorology, 3, 80-91, 2002.

460 Santa Catarina: Atlas de Santa Catarina, Gabinete de Planejamento e Coordenação Geral. Subchefia de Estatistica, Geografia e Informatica. Rio de Janeiro: Aerofoto Cruzeiro, 1986.

Schoups, G. and Vrugt, J. A.: A formal likelihood function for parameter and predictive inference of hydrologic models with correlated, heteroscedastic, and non-Gaussian errors, Water Resources Research, 46, https://doi.org/10.1029/2009WR008933, 2010.

Sheikh, V., Visser, S., and Stroosnijder, L.: A simple model to predict soil moisture: Bridging Event and Continuous Hydrological (BEACH) modelling., Environmental Modelling and Software, 24, 542-556, https://doi.org/http://dx.doi.org/10.1016/j.envsoft.2008.10.005, 2009.

Shuin, Y., Otsuka, I., and Matsue, K.: Estimation of Shallow Landslides Caused by Heavy Rainfall Using Two Conceptual Models, International Journal of Erosion Control Engineering, 7, 92-100, 2013.

Sohrabi, M. M., Ryu, J. H., Abatzoglou, J., and Tracy, J.: Development of Soil Moisture Drought Index to Characterize Droughts, Journal of Hydrologic Engineering, 21, https://doi.org/10.1061/(ASCE)HE.1943-5584.0001358, 2016.

Sørensen, R., Zinko, U., and Seibert, J.: On the calculation of the topographic wetness index: evaluation of different methods based on field observations, Hydrology and Earth System Sciences, 10, 101-112, https://doi.org/10.5194/hess-10-101-2006, https://www. hydrol-earth-syst-sci.net/10/101/2006/, 2006.

Sugawara, M.: On the Analysis of Runoff Structure about Several Japanese Rivers, Japanese Journal of Geophysics, 2, 1-76, 1961.

Sugawara, M.: Tank Model. In: SINGH, V.P.(Ed.). Computer Models of Watershed Hydrology, Highlands Ranch: Water Resources Publications, pp. 165-214, 1995.

Takahashi, T. and Nakagawa, H.: Prediction of stony debris flow induced by severe rainfall, JSECE, 44, 12-19, 1991.

Tarboton, D. G.: A new method for the determination of flow directions and upslope areas in grid digital elevation models, Water Resources Research, 33, 309-319, https://doi.org/10.1029/96WR03137, 1997.

Tavares da Costa, R., Manfreda, S., Luzzi, V., Samela, C., Mazzoli, P., Castellarin, A., and Bagli, S.: A web application for hydrogeomorphic flood hazard mapping, Environmental Modelling \& Software, 118, 172-186, 2019.

Tingsanchali, T. and Gautam, M. R.: Application of tank, NAM, ARMA and neural network models to flood forecasting, Hydrological Processes, 14, 2473-2487, https://doi.org/10.1002/1099-1085(20001015)14:14<2473::AID-HYP109>3.0.CO;2-J, 2000.

Uber, M., Vandervaere, J., Zin, I., Braud, I., Heistermann, M., Legoût, C., Molinie, G., and Nord, G.: How does initial soil moisture influence the hydrological response A case study from southern France, Hydrology and Earth System Sciences, 22, 6127-6146, https://doi.org/10.5194/hess-22-6127-2018, 2018.

Vachaud, G., Passerat de Silans, A., Balabanis, P., and Vauclin, M.: Temporal stability of spatially measured soil water probability density function, Soil Science Society of America Journal, 49, 822-827, 1985.

Van Genuchten, M.: A Closed-form Equation for Predicting the Hydraulic Conductivity of Unsaturated Soils1, Soil Science Society of America Journal, 44, https://doi.org/10.2136/sssaj1980.03615995004400050002x, 1980. 
https://doi.org/10.5194/hess-2019-682

Preprint. Discussion started: 28 January 2020

(c) Author(s) 2020. CC BY 4.0 License.

(c) (1)

Van Genuchten, M., Leij, F., and Yates, S.: The RETC Code for Quantifying the Hydraulic Functions of Unsaturated Soils, Version 1.0 EPA Report 600/2-91/065, U.S. Salinity Laboratory, USDA, ARS, Riverside, California, 1991.

Vrugt, J.: Markov chain Monte Carlo simulation using the DREAM software package: theory, concepts, and MATLAB implementation, Environmental Modelling and Software, 75, 273-316, 2016.

Walker, J. P., Willgoose, G. R., and Kalma, J. D.: In situ measurement of soil moisture: a comparison of techniques, NOVA. The University of Newcastle's Digital Repository, 2004.

Western, A. W. and Bloschl, G.: On the spatial scaling of soil moisture, Journal of Hydrology, 217, 203 - 224, https://doi.org/https://doi.org/10.1016/S0022-1694(98)00232-7, 1999.

Western, A. W., Bloschl, G., and Grayson, R. B.: Geostatistical characterisation of soil moisture patterns in the Tarrawarra catchment, Journal of Hydrology, 205, 20 - 37, https://doi.org/https://doi.org/10.1016/S0022-1694(97)00142-X, 1998.

500 Western, A. W., Grayson, R. B., Blöschl, G., Willgoose, G. R., and McMahon, T. A.: Observed spatial organization of soil moisture and its relation to terrain indices, Water Resources Research, 35, 797-810, https://doi.org/10.1029/1998WR900065, 1999.

World Metereological Organization (WMO): Intercomparison of conceptual models used in operational hydrological forecasting, Tech. Rep. 7, WMO No. 429, Oper Hydrol, 1975.

World Metereological Organization (WMO): Simulated real-time inter-comparison of hydrological models, Tech. Rep. 38, WMO No. 779, Oper Hydrol, 1992.

Yang, Y., Dou, Y., Liu, D., and An, S.: Spatial pattern and heterogeneity of soil moisture along a transect in a small catchment on the Loess Plateau, Journal of Hydrology, 550, 466 - 477, https://doi.org/https://doi.org/10.1016/j.jhydrol.2017.05.026, 2017.

Zehe, E. and Sivapalan, M.: Threshold behaviour in hydrological systems as (human) geo-ecosystems: manifestations, controls, implications, Hydrology and Earth System Sciences, 13, 1273-1297, https://doi.org/10.5194/hess-13-1273-2009, 2009.

510 Zehe, E., Elsenbeer, H., Lindenmaier, F., Karsten, S., and Blöschl, G.: Patterns of predictability in hydrological threshold systems, Water Resources Research, 43, https://doi.org/10.1029/2006WR005589, 2007.

Zheng, X., Tarboton, D. G., Maidment, D. R., Liu, Y. Y., and Passalacqua, P.: River Channel Geometry and Rating Curve Estimation Using Height above the Nearest Drainage, JAWRA Journal of the American Water Resources Association, 54, 785-806, https://doi.org/10.1111/1752-1688.12661, 2018.

515 Zhuo, L. and Han, D.: Multi-source hydrological soil moisture state estimation using data fusion optimisation, Hydrology and Earth System Sciences, 21, 3267-3285, https://doi.org/10.5194/hess-21-3267-2017, https://www.hydrol-earth-syst-sci.net/21/3267/2017/, 2017. 